\title{
African community-based conservation: a systematic review of social and ecological outcomes
}

\author{
$\underline{\text { Kathleen A. Galvin }}^{1}$, Tyler A. Beeton ${ }^{2,3}$ and Matthew W. Luizza ${ }^{3}$
}

\begin{abstract}
Community-based conservation (CBC) institutions are widely regarded as transformative bodies that benefit social and ecological processes in coupled social-ecological systems. Yet, limited empirical evidence for this claim exists, especially on the African continent where community-based conservancies (CBCs) are being rapidly adopted in diverse institutional forms across multiple countries. We provide the first large-scale systematic review of CBC outcomes in sub-Saharan Africa. We review the literature on CBCs and develop a conceptual model that illustrates the nested scales of interaction in which $\mathrm{CBCs}$ are embedded, the institutional processes ("conditions") reported as important for success, and the outcomes of CBCs on social and ecological systems. The mixed-method approach consists of inductive/deductive textual analysis of cases, geospatial visualization, descriptive statistics, and correlational analysis. Results indicate that more often than not, establishment of CBCs in Africa has led to negative or a mixture of positive and negative social outcomes, whereas ecological outcomes have been largely positive. The research conducted on CBC institutions has overwhelmingly focused on social outcomes, using qualitative methods. Monetary and nonmonetary incentives seem to be important but not sufficient on their own for positive outcomes. Devolution of rights to the local community is significantly associated with CBC outcomes but was not present in many cases, despite this feature being a hallmark of CBCs. A number of conditions were not reported in the cases reviewed, including leadership, social learning, consideration of cultural worldviews, and diverse partnerships. We provide indepth examples of the types and diversity of outcomes and contexts underpinning the presence or absence of societal processes, highlight important gaps in the existing research, and offer guidelines for research and evaluation moving forward.
\end{abstract}

Key Words: Africa; community-based conservation; conditions; evaluation; social and ecological outcomes; systematic review

\section{INTRODUCTION}

Community-based conservation $(\mathrm{CBC})$ is regarded as a suite of transformational institutional arrangements, the goal of which is to enhance human social well-being and sustain biodiversity through conservation-development initiatives (Ostrom 1990, Berkes 2004, 2007, Seixas and Davy 2008, Seixas and Berkes 2010). Although CBC institutions are touted as win-win solutions, there is little empirical evidence that supports enhanced conservation and development, especially in Africa (Songorwa et al. 2000, Bray et al. 2003, Blaikie 2006, Duffy 2006, Kothari 2006, Berkes 2007, Hoole 2007, Seixas and Davy 2008, Roe et al. 2009, Awung and Marchant 2016). Relatedly, efforts to monitor and evaluate the outcomes of such initiatives are piecemeal (Barrett et al. 2011) and often fail to incorporate social impact monitoring results back into ongoing conservation efforts (Kaplan-Hallam and Bennett 2017). Institutional factors have been thoroughly examined around management of natural resources held as commons, and a large set of factors that enable sustainability have been defined (e.g., Agrawal 2001). For example, Ostrom (1990) used institutional analysis of empirical data to explore the different ways in which commons are governed. However, relatively few studies have examined the institutional factors that enhance social and ecological outcomes of community-based conservancies (CBCs) in Africa (Agrawal and Redford 2009, Robinson and Berkes 2011, Upton 2012, Brooks et al. 2012, Goldman and Riosmena 2013). Therefore, there is an urgent need to evaluate the social and ecological outcomes of African CBCs, and the institutional processes that may lead to their success or failure.
We systematically review the state and components of $\mathrm{CBC}$ in sub-Saharan Africa, with a specific focus on outcomes of measures of human well-being and biodiversity conservation. The objectives of this include (1) the development of a conceptual framework for evaluating the institutional processes and social and ecological outcomes of CBCs; (2) identification of the primary study measures, method of inquiry, CBC governance types, goals, conservancy activities, and local livelihood activities on the continent; (3) review of positive and negative social and ecological outcomes; (4) review of a subset of institutional processes proposed from the literature as important "conditions" for success or failure; and (5) identification of major gaps in $\mathrm{CBC}$ literature in Africa to support future research and evaluation of this institutional form throughout the continent and beyond.

Community-based conservation is an evolving concept, but for the purpose of this study, we define CBC broadly as an institution that simultaneously enhances human development-especially for people living directly with nature - and conserves biodiversity. Community-based conservation institutions offer incentives to sustainably manage natural resources and have some measure of devolution of resource management responsibilities (Berkes 2007, Plummer and Armitage 2007, Suich 2010, Morton et al. 2016). Local land users are thought to be ideally central to crafting and implementing conservation and development initiatives in a CBC model (Agrawal 2003, Armitage 2005, Black and Cobbinah 2017). We understand that the goals of CBCs are much debated in the literature, especially in the "parks versus people" dispute wherein protected areas conservation policy is firm on human absence versus "social conservationists" , focus on conservation-oriented

${ }^{1}$ Department of Anthropology, Colorado State University, ${ }^{2}$ North Central Climate Adaptation Science Center, ${ }^{3}$ Natural Resource Ecology Laboratory, Colorado State University 
Fig. 1. Community-based conservation (CBC) conceptual model adapted from Berkes (2004, 2007), Plummer and Armitage (2007), Seixas and Davy (2008), and Seixas and Berkes (2010), among others. An array of components existing within and beyond $\mathrm{CBC}$ institutions interact to influence the sustainable and unsustainable social and ecological outcomes of their actions. This includes exogenous drivers of $\mathrm{CBC}$ formation such as ecology, climate, social, political, and economic factors, which occur across scales (local to global), as well as the processes that shape and are shaped by $\mathrm{CBC}$ institution goals. We focus our review on the types of outcomes reported and the institutional processes, or conditions, thought to lead to successful outcomes.

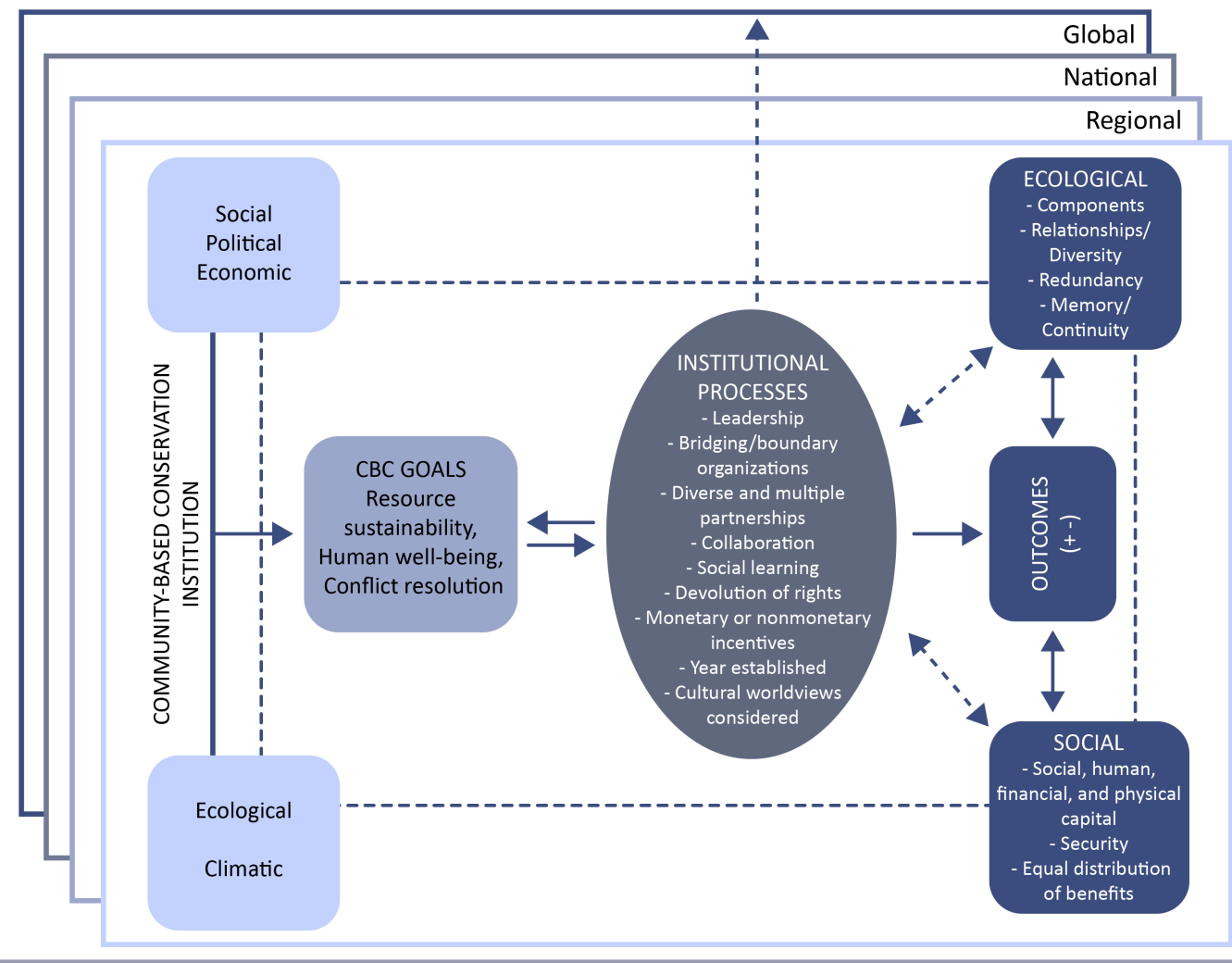

development (e.g., Miller et al. 2011). In our view, this dichotomy may be a bit displaced because even protected areas have local communities living around them that impact local resource conditions and flows, and in turn are impacted by protected area management decisions (Hansen et al. 2011, Cumming 2016, Mathevet et al. 2016). We do not refute or value one view of conservation over the other. We specifically look at social and ecological outcomes and some of the conditions that are stated to favor both among CBCs.

Common pool resources such as forests, grasslands, and oceans are often managed as common property by a wide variety of institutional arrangements that are governmental, private, or community owned (Ostrom 2008). Sub-Saharan Africa has adopted $\mathrm{CBC}$ institutions in the last 30 years as a means to combine rural development and conservation efforts within the context of decentralized authority over land and natural resources. Community-based conservation is promoted as a means to re-aggregate the common resource, provide biodiversity conservation, and enhance human livelihoods under increasing pressures from population growth, land use changes, and other forces (e.g., Galvin 2009, Reid et al. 2014). While there is no fixed set of governance institutions that are appropriate to effectively govern resources (Ostrom 2007, Andersson and Ostrom 2008), CBC institutions are often exemplified by nongovernmental organizations (NGOs), private individuals, and layers of government that represent, facilitate, or at least support local communities in conservation governance and resource management (Baival and Fernández-Giménez 2012). These institutions are diverse in practice, encompassing an array of activities and descriptive labels such as community-based conservancies, wildlife partnerships, community-based natural resource management, indigenous resource management programs, and integrated conservation and development initiatives, but with the central idea of "the coexistence of people and nature, as distinct from protectionism and the segregation of people and nature" (Western and Wright 1994:8). A key assumption is that socioeconomic incentives for participation in CBC allow local populations to maintain biodiversity, increase their socioeconomic status, and support economic development more generally (Andersson and Ostrom 2008, Taylor 2009, Dougill et al. 2012, Mace 2014). 


\section{MATERIALS AND METHODS}

\section{Analytical framework}

We developed a conceptual model of the components of CBCs (Fig. 1). The model is informed by the $\mathrm{CBC}$ adaptive comanagement, adaptive governance, and sustainable livelihoods literature (e.g. Chambers and Conway 1992, Scoones 1998, DFID 1999, Berkes 2004, 2007, Plummer and Armitage 2007, Seixas and Davy 2008, Armitage et al. 2009, Seixas and Berkes 2010). Fig. 1 is used here not as an idealized typology but as a useful heuristic to frame the analysis. The framework contains the following main components: (1) the broad social and ecological contexts that drive $\mathrm{CBC}$ formation and development (e.g., social, political, economic, ecological, climatic) within the context of the region, nation, and globe; (2) CBC goals; (3) institutional processes (or conditions) that have been considered important components for success in CBCs and other community-based initiatives; and (4) social and ecological outcomes. While the broad drivers that influence the development of CBCs are highlighted on the left of the framework, they are not the subject of the current analysis.

Society and its embedded power relationships in policy, economics, and culture, for example, drive CBC goals and internal CBC processes, as do the ecological assets (as influenced through climate and environment). Both macropolitical processes and resource changes are salient to the explanation of institutional goals, how they work, and institutional change (Gibson 1999). Though CBC is defined by local input, a decentralized system that relies solely on the self-organization of local resource users has not generally been realized. This is in large part because national governments rarely devolve governance completely (Ribot et al. 2010), or it has been too costly in terms of funding, self-organization, and/or politics to be successful (Andersson and Ostrom 2008). Thus, there is a need for partnerships for CBCs to function. The partners may be political, social, or economic from the local to national to access resources, build trust, resolve conflict, and provide networking, or they may be knowledgebased that mobilize knowledge at different scales (e.g., NGOs, county and state governments, universities, and others) (Berkes 2007).

Within these partnerships it is important to determine if the conservation model employed is compatible with cultural worldviews regarding people-nature relationships and that $\mathrm{CBC}$ goals and activities do not infringe on local livelihood practices. This is often emphasized through discussions of incorporating diverse forms of knowledge (e.g., Local and Traditional Ecological Knowledge) into CBC projects and developing a crosscultural conservation ethic that promotes appropriate conservation incentives (Berkes 2004, Tengö et al. 2014), while acknowledging that conservation can have multiple objectives and stakeholders, which requires context-specific interventions (Gavin et al. 2015).

Community-based conservation institutions are linked together laterally and nested within levels of governance vertically (e.g., NGOs, national government, industry) that affect their internal functioning (Ostrom et al. 2002). Nongovernmental organizations and other groups provide a range of bridging services, including start-up funds, institution building skills, marketing, technical training, research, knowledge transfer, and social services (Seixas and Berkes 2010). Government organizations are important for political or legal support or at least for not creating barriers. Supporting organizations and institutional partners (often called boundary or bridging organizations) are needed in an increasingly globalized world at both lateral (providing bonding ties) and/or vertical (providing bridging ties) levels (Berkes 2004, 2007). They operate at various social-organizational scales to provide a platform through which joint governance takes place (Berkes 2009, Seixas and Berkes 2010). Ideally, management involves both bonding and bridging ties for shared learning-by-doing between the various actors (Plummer et al. 2012, 2013). The types and number of institutional interactions are often associated with the development phase of a CBC - i.e., the length of time they have been in existence (Seixas et al. 2009, Seixas and Berkes 2010) and their needs as they change over time. Thus, a CBC could be understood as in a continuous problem-solving process through time.

There are myriad factors that determine the social and ecological outcomes of CBCs, which include exogenous socio-political, economic, historical, and biophysical factors, in addition to the local conditions and processes in which CBCs operate. In the context of Fig. 1, however, we frame our analysis on a small subset of institutional processes $(n=10)$ that have been argued to be important to successful outcomes in CBCs. In this case, institutional processes that are associated with positive social and ecological outcomes include strong, visionary leadership; nested, diverse institutional linkages and partnerships; presence of boundary organizations; collaboration; the ability for social learning; consideration of cultural worldviews in $\mathrm{CBC}$ development and management; devolution of rights to local communities; a sufficient amount of time since emergence; and both monetary and nonmonetary incentives.

Social outcomes can be measured by assessing the asset or capital stock held by individuals and households. Plummer and Armitage (2007) and others (DFID 1999, Igoe 2006) describe the capitals, including social capital that encompasses networks, rules, and relationships of trust. Financial capital includes cash, credit, and assets, such as livestock. Human capital includes knowledge, skills, or other benefits from conservation programs. Physical capital includes infrastructure, and transportation and communication services. Ecological outcomes, a subset of natural capital, include all abiotic and biotic ecosystem components (components), ecosystem processes such as nutrient cycling and vegetation changes (relationships and functions), species richness and diversity (diversity), and memory and continuity. Plummer and Armitage (2007) define them as the components and processes in nature that are considered essential to environmental sustainability. The ecological outcomes are also comprised of what Cumming et al. (2015) term "ecological solidarity" and what Diaz et al. (2015) term intrinsic values of nature in addition to nature's benefits to people. These institutional processes and outcomes outlined in Fig. 1 and explained here serve as the codes and concepts that frame the textual analysis. More information on the processes and outcomes, how we define them for this study, and relevant sources can be found in Appendix 1.

While the framework for CBC evaluation is process-oriented and dynamic, we acknowledge that a review is a bit of a blunt instrument. There are other factors that may need to be considered in order to effectively assess the state and outcomes of CBCs, 
which must be tailored to local contexts. Yet, we argue that this framework is a useful starting point to evaluate the state and outcomes of CBCs.

\section{Method: review of case studies}

We employed a systematic review (Ford et al. 2011, Brooks et al. 2012, Waddington et al. 2012, Berrang-Ford et al. 2015, Haddaway et al. 2015) of the CBC literature across sub-Saharan Africa. Systematic reviews are useful to summarize and assess the state of knowledge concerning a research question, and provide the means to identify gaps and needs for future research (Ford and Pearce 2010). Systematic reviews are becoming more common in environmental research (e.g., Berrang-Ford et al. 2015, Haddaway et al. 2015, Leisher et al. 2016, Fagerholm et al. 2016, McKinnon et al.2016), and are an attempt to enhance replicability and transparency of research methods and reduce subjectivity in analysis of results. Although there is no "one-size-fits-all" approach for systematic reviews, which should be tailored for the specific context in which they are being used (Berrang-Ford et al. 2015), there is a suite of guidelines, or principles, that set them apart from nonsystematic literature reviews, such as (1) clearly formulated research questions/scope; (2) inclusion of a theoretical or conceptual framework to guide the review; (3) articulation of the types and extent of literature reviewed, including search terms used and justification of those terms, along with clearly defined inclusion and exclusion criteria; and (4) explicit description of data analysis (Ford et al. 2011, Berrang-Ford et al. 2015, Haddaway et al. 2015).

The focus of this review is on (1) the types and diversity of social and ecological outcomes that are reported in the literature, and (2) the institutional processes, or conditions, that have been proposed as important to the success of CBCs. The conceptual framework guided the documentation of social and ecological outcomes and institutional conditions, and therefore provided a methodologically transparent and rigorous tracking and synthesis of CBC data (Fig. 1). Specifically, we developed a code list based on the conceptual framework and definitions of concepts from the literature (Appendix 1) to document the positive, negative, and mixed social-ecological outcomes and the presence or absence of a set of institutional processes for each case based on case author's descriptions. We then tested whether or not these institutional variables were associated with positive or negative social-ecological outcomes. For each case, we also identified descriptive characteristics relevant to each case, including study measure; that is, whether the focus was on social and/or ecological outcomes, method of inquiry, governance type, goals, conservancy activities, and local livelihood activities. We now outline the search strategy, inclusion and exclusion criteria, and analysis.

\section{Retrieval and inclusion/exclusion of case studies}

To determine the studies for the review, an extensive Web of Science and Google Scholar search was conducted based on key search terms, which included the following: "community-based conservancies," "integrated conservation and development programs," "community-based natural resource management," "community-based conservation," "community-based wildlife management," and "collaborative wildlife management." These search terms were identified within the seminal body of literature used to develop our CBC conceptual model (Fig. 1) and were further validated through the co-authors' collective 25 years of experience conducting interdisciplinary social and ecological research in Africa, and additional consultation with an African CBC expert. Term searches were conducted first in Web of Science. Google Scholar search results were screened by title and cross-referenced with Web of Science search results to identify new cases not already accounted for and in need of abstract screening. In addition to identifying peer-reviewed journal articles, grey literature was included (i.e., published and unpublished reports of government agencies, NGOs, and other relevant institutions not accessible through online journal repositories) (Fig. 2). Grey literature sources were identified through a Google Scholar search of each of the key search terms and were supplemented by a review of websites for two major CBC organizations operating in Africa (Northern Rangelands Trust and Namibian Association of Community Based Natural Resource Management Support Organisations). Though the search retrieved seven MSc and PhD theses, we excluded them. In our initial analysis and exclusion process, we discovered that three of these (Hoole 2008, Glew 2012, and Bedelian 2014) published major findings from their dissertation work in the peerreviewed literature that was included in our analysis. It was at this stage that we decided to omit MSc and PhD theses, though all of them were $\mathrm{read} /$ reviewed in an ad-hoc manner. The search was restricted to English-language journals and grey literature; therefore, we potentially overlooked a number of applicable cases in French-, Portuguese-, and Spanish-language journals covering Francophone Africa (West and Central), Lusophone Africa (Angola, Guinea-Bissau, Mozambique), and Equatorial Guinea, respectively.

Fig. 2. Flow chart illustrating the process of choosing community-based conservation (CBC) studies for inclusion in the review (adapted from McKinnon et al. 2016). Potential sources were identified through Web of Science and Google Scholar database searches of key CBC institution terms $(n=$ 47,852). This initial pool of manuscripts and reports was further screened by the title and abstract for inclusion in the full text review $(n=111)$. The final number of cases included in the spatial analysis and detailed analysis were 73 and 65 , respectively.

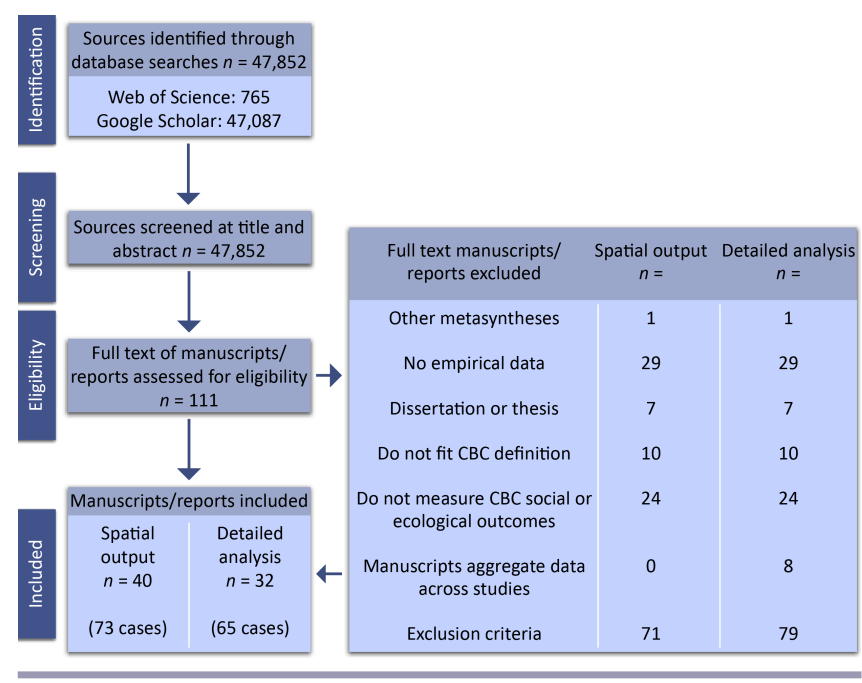


Titles and abstracts were assessed to determine if the institution in question fit the broad criteria of community-based conservation (i.e., conservation groups that seek the joint goals of biodiversity conservation and improved rural livelihoods by providing incentives to sustainably manage relevant resources [Suich 2010:45]). This resulted in an initial pool of 111 papers/ reports, spanning 18 African countries (Fig. 2).

Papers were then excluded based on the following criteria (number of papers excluded due to these criteria are in parentheses): other metasyntheses (1), papers that did not provide empirical data (29), $\mathrm{PhD}$ dissertations or Master's theses (7), papers that did not ultimately fit the criteria of a CBC institution (10), or papers that did not measure social and/or ecological outcomes of CBCs (23). The initial pool was refined into two groups of papers: one for mapping the spatial distribution of broad key findings and another for more detailed analysis of reported outcomes and institutional processes that have been identified as important to CBC success. For the more detailed analysis, papers that aggregated data from multiple case studies (8) were additionally excluded to allow a more accurate assessment of individual CBC cases (Fig. 2). For the spatial analysis, this resulted in 40 papers (38 peer-reviewed publications and two grey literature reports), comprised of 73 individual and aggregated case studies spanning the past 20 years and covering 12 African countries (Fig. 3) (see Appendix 2 for case data). For the detailed analysis of outcomes and processes, this included 32 papers (30 peer-reviewed publications and two grey literature reports), comprised of 65 individual case studies spanning the past 20 years and covering 11 African countries (see Appendix 3 for case data). Appendix 4 lists all the papers that were ultimately excluded.

Fig. 3. Location and number of cases included in the review.

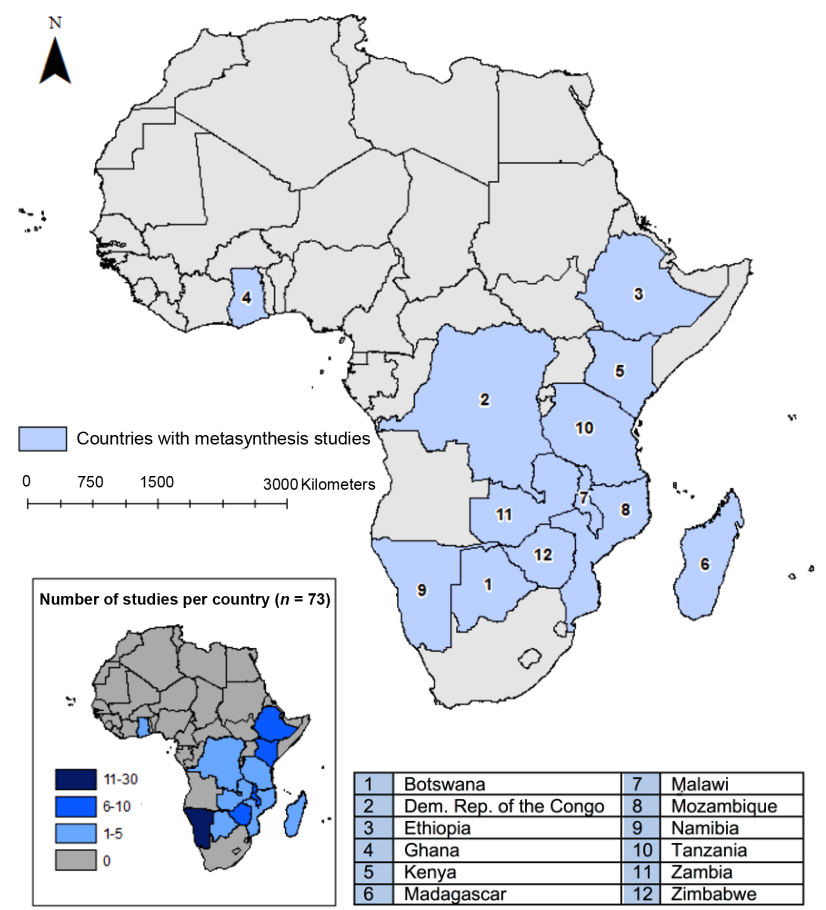

\section{Data analyses}

We used a mixed methods approach for this systematic review (e.g., Ford et al. 2011), which consisted first of coding outcomes and institutional processes for each case study, followed by geospatial analysis, descriptive statistics, and correlational analysis. The textual analysis was carried out in a series of steps and relied on inductive and deductive coding. First, each case was read in entirety and coded for the broad outcomes (e.g., positive, negative, mixed), method of inquiry (e.g., social, ecological, social-ecological), governance type ${ }^{[1]}$ (public-public, public-private, private-private), $\mathrm{CBC}$ goals and activities, and livelihood practices (Appendix 2). For each category, summary statistics were converted into pie charts and displayed on a map of the African continent, which was created in ArcGIS software (v.10.3.1) for spatial visualization (e.g., McKinnon et al. 2016).

Next, the cases included in the detailed analysis were read again, during which we coded and analyzed (a) social and ecological outcomes, and (b) a subset of institutional processes $(n=10)$, or conditions. Outcomes were coded as positive, negative, mixed, or missing. Definitions used to code outcomes were based on DFID (1999) and from Plummer and Armitage (2007) (Appendix 1). In this vein, we coded outcomes for each case according to individual capital assets (e.g., financial capital) and ecological parameters (e.g., memory and continuity), as well as determined an overall outcome. To determine overall outcomes for each case study, we relied on the original authors' interpretation. In most cases, this was straightforward. In cases where authors reported both positive and negative outcomes, and did not indicate directionality, we coded the case as mixed. However, this was relatively rare; in most cases where positive and negative benefits were described, the author still made clear the overall outcome. For instance, in some cases, some members of the $\mathrm{CBC}$ might have received financial benefits, yet these were sparse, unevenly distributed, and typically did not outweigh the costs of CBC for most households (e.g., Suich 2013, Silva and Mosimane 2014). In these situations, the authors indicated, and we coded, a negative outcome. We acknowledge that this introduces some subjectivity into the coding process, but we took steps to reduce subjectivity.

Institutional processes $(n=10)$ were coded as dichotomous variables (present/absent). We also noted where cases did not report on a condition (missing) to identify gaps in the literature; i.e., we did not presume that failure to report on a condition was evidence of absence. Definitions of these codes were based on literature reviewed in the Analytical Framework section, and were modified, expanded, and refined based on review of the cases particular to this review (Appendix 1).

The ways in which outcomes and institutional processes were reported in the cases were contextual and nuanced, which derived from the fact that many cases were indepth, qualitative studies, and many of the institutional processes reported in the literature are multidimensional. Therefore, we took steps to increase transparency and replicability, and reduce subjectivity. First, as mentioned, the code definitions and inclusion criteria for each code were derived from the conceptual framework and relevant literature, and we provide clear documentation of those codes, how we defined them, examples, and sources (Appendix 1). Second, we provide spreadsheets that document each case 
included in the spatial and detailed analysis and how each was coded, along with a list of those cases that were excluded (Appendix 2, 3, and 4, respectively). Third, we employed an iterative and collaborative coding approach to enhance intercoder reliability (Tinsley and Weiss 2000). Two coders (TB and ML) read and coded the same cases independently, and then discussed inclusion/exclusion criteria for individual codes, coding issues, and memos to distil and align their interpretations. It was during this time that definitions and descriptions of the codes were modified, expanded, and refined accordingly. The coders then came together at regular intervals to review each of the cases and coding instances.

Once each case was coded, qualitative and quantitative reports were extracted from Atlas.ti, a qualitative data analysis software program. Descriptive statistics were used to describe the type and variety of social and ecological outcomes, and the presence or absence of institutional conditions as they were reported in each case. The Fisher exact test was used to test the association between institutional processes and $\mathrm{CBC}$ outcomes. Sample size limited further statistical investigation. Descriptive statistics and correlational analyses were supplemented with qualitative information to provide some contextual interpretation of the diversity in outcomes and institutional processes.

\section{RESULTS}

\section{Spatial analyses}

Community-based conservation institutions in Africa produced positive outcomes in less than half of the cases assessed, and the research conducted on them has overwhelmingly focused on social outcomes, using qualitative methods (see Appendix 2 for the map data). Of the $73 \mathrm{CBC}$ cases assessed in the spatial analysis, $48 \%$ (35 cases) were reported as having positive outcomes, $36 \%$ (26 cases) as having negative outcomes, and 16\% (12 cases) as having a mixture of positive and negative outcomes (Fig. 4). Most cases measured social outcomes ( 54 cases; $74 \%$ ), whereas just nine and 10 cases, respectively ( $12 \%$ and $14 \%)$, measured ecological outcomes or a mixture of social and ecological outcomes (Fig. 5). Furthermore, most cases employed qualitative methods ( 51 cases; $70 \%)$, compared to only 12 and 10 cases, respectively $(16 \%$ and $14 \%$ ), that used quantitative or a mixture of qualitative and quantitative methods. Governance arrangements were predominately reported as public-public (45 cases; 62\%), compared to far fewer public-private $(24$ cases; $33 \%$ ) or private-private (3 cases; $4 \%$ ) arrangements. The most prevalent CBC goals included wildlife/ habitat conservation ( 47 cases; $64 \%$ ), socioeconomic development ( 39 cases; $53 \%$ ), and sustainable resource use ( 24 cases; $33 \%$ ). The most common CBC activities reported were ecotourism (43 cases; $59 \%$ ), hunting (37 cases; 51\%), and sustainable grazing and forest products (14 cases each; 19\%). The most prevalent livelihood activities of local people living in and around a CBC institution included livestock husbandry (46 cases; 63\%), farming (45 cases; $62 \%$ ), and ecotourism ( 21 cases; $29 \%$ ).

\section{Social and ecological outcomes}

The cases reviewed in the detailed analysis disproportionately addressed social outcomes: $86 \%$ of cases $(n=56)$ reported social outcomes, while only $28 \%$ of cases $(n=18)$ addressed ecological outcomes (Table 1). Nine cases evaluated social and ecological outcomes; for these, all cases reported both positive social and ecological outcomes or both negative social and ecological outcomes, save for one case (Glew et al. 2010). Among the cases reviewed here, the establishment of $\mathrm{CBCs}$ has led to more negative social outcomes than positive, while the remaining cases $(n=11$; $20 \%$ ) reported mixed outcomes (both positive and negative social outcomes). On the other hand, of the cases that reported ecological outcomes, most reported that the establishment of a $\mathrm{CBC}$ has led to positive outcomes $(n=14 ; 78 \%)$. Only four cases reported negative or mixed ecological outcomes.

Fig. 4. Key outcomes of community-based conservation (CBC): positive outcomes (48\%; 35 cases), negative outcomes $(36 \% ; 26$ cases), and mixed outcomes (16\%;12 cases).

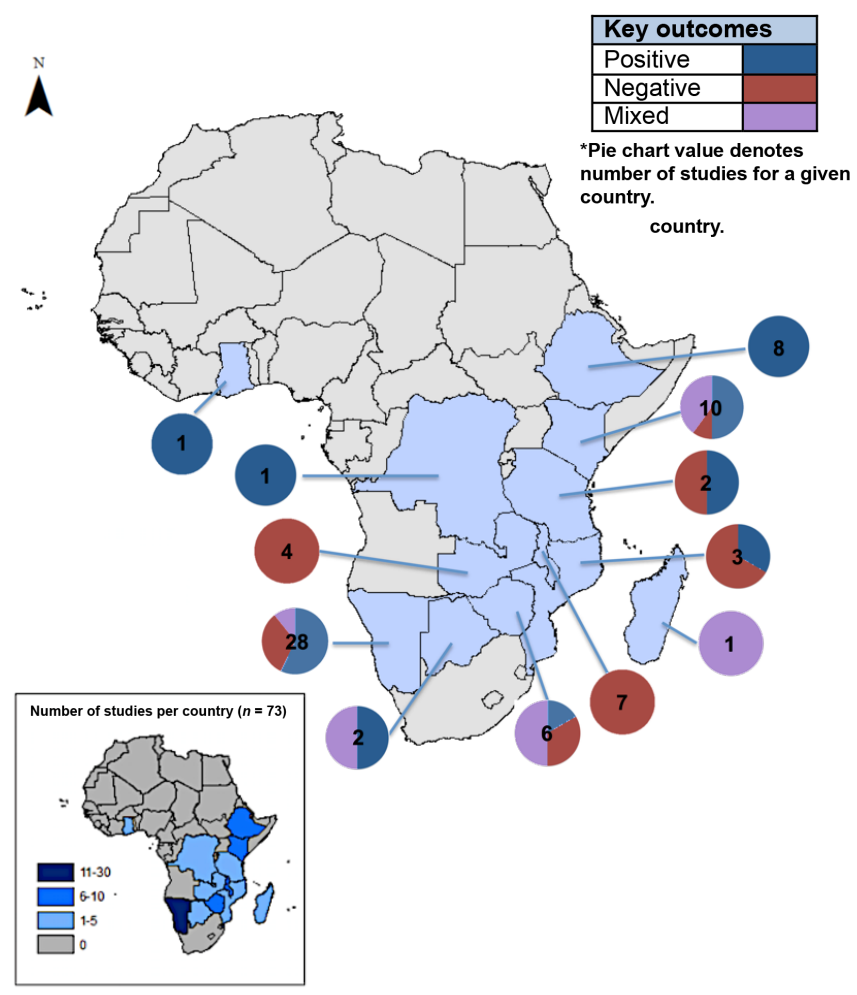

Social outcomes

Cases with positive social outcomes were related predominantly to financial capital and human capital, and cases of negative social outcomes were related principally to unequal distribution of benefits and reduced social capital (Fig. 6). Positive financial capital outcomes included direct payment schemes, where $\mathrm{CBC}$ members and/or landowners received cash dividends either as a proportion of visitation sales or at a fixed rate per lease agreement (e.g., Scanlon and Kull 2009, Sheppard et al. 2010, Snyman 2012, Osano et al. 2013), or in some cases, livestock (Silva and Mosimane 2014); full- and part-time employment opportunities with joint venture tourism operators and/or as staff members with the CBC (e.g., Scanlon and Kull 2009, Glew et al. 2010, Lapeyre 2010, Greiner 2012, Snyman 2012, Osano et al. 2013, Silva and Mosimane 2014); diversification opportunities and additional revenue streams, such as the organic shea nut collective in the Wechiau Community Hippo Sanctuary, Ghana (Sheppard et al. 
Fig. 5. Multiple map inset. Study measures for community-based conservation (CBC) research: social (54 studies; $74 \%$ ), mixed ([i.e., social and ecological] 10 studies; 14\%), ecological (9 studies; $12 \%$ ). Study methods for CBC research: qualitative (51 studies; $70 \%$ ), quantitative (12 studies; 16\%), mixed ([i.e., qualitative and quantitative] 10 studies; 14\%). Community-based conservation governance: public-public (45 studies, 62\%), public-private (24 studies; 33\%), private-private (3 studies; 4\%), not reported (1 study; $1 \%$ ). Community-based conservation goals: wildlife/habitat conservation (47 studies; 64\%), poverty alleviation (12 studies; $16 \%$ ), environmental education ( 2 studies; 3\%), sustainable resource use ( 24 studies; 33\%), socioeconomic development (39 studies; 53\%), conflict resolution ( 9 studies; $12 \%$ ), sustainable farming ( 9 studies; 12\%), management decentralization (10 studies; 14\%), equitable water distribution ( 8 studies; $11 \%$ ), pest prevention ( 8 studies; $11 \%)$, report to local government ( 1 study; $1 \%)$, infrastructure development ( 8 studies; 11\%), not reported (1 study; 1\%). Community-based conservation activities: ecotourism (43 studies; 59\%), hunting (37 studies; 51\%), farming (12 studies; 16\%), wildlife/habitat conservation ( 8 studies; 11\%), fishing ( 1 study; $1 \%$ ), forest products (14 studies; 19\%), sustainable grazing (14 studies; 19\%), logging (7 studies; 10\%), wetland products (8 studies; $11 \%)$, craft markets (6 studies; $8 \%$ ), mining ( 1 study; 1\%), live game sales ( 1 study; $1 \%$ ), honey production ( 1 study; $1 \%$ ), not reported (1 study; 1\%). Local livelihoods: livestock (46 studies; 63\%), farming (45 studies; 62\%), ecotourism (21 studies; $29 \%$ ), hunting (16 studies; $22 \%$ ), forest products (18 studies; $25 \%$ ), fishing (4 studies; $5 \%$ ), logging ( 7 studies; $10 \%)$, wetland products $(8$ studies; $11 \%)$, mining (3 studies; 4\%), not reported (8 studies; 11\%), relief assistance (3 studies; $4 \%$ ).
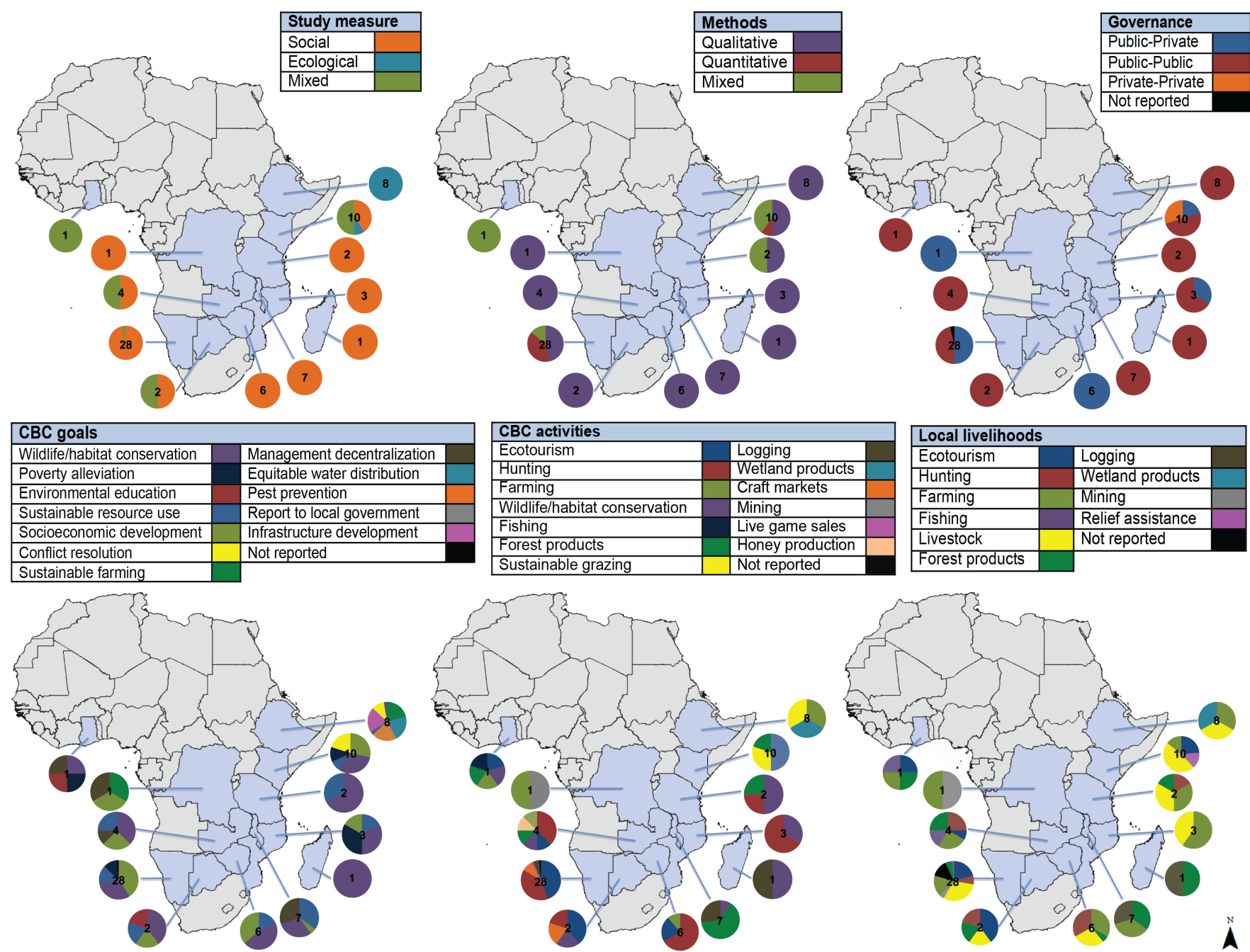

*Pie chart value denotes number of studies for a given country.

2010), and the Amani Butterfly Project, Tanzania (MorganBrown et al. 2010); and finally, stock-loss compensation schemes, which were considered particularly important when enhanced tourism and $\mathrm{CBC}$ efforts in local places resulted in increased human-wildlife and livestock-wildlife conflicts (e.g., Scanlon and Kull 2009).
Human capital benefits in cases with positive social outcomes included increased access to education, medical care, nutritional foods, firewood, transportation, training and extension support services, and enhanced security. In some cases, CBC members used financial capital assets received from $\mathrm{CBC}$ membership to pay for school fees, medical supplies, and visits to clinics (e.g., 
Table 1. Total number and percent of cases that addressed social and ecological outcomes of community-based conservation $(n=65)$, and the relative proportion of cases that reported positive, negative, and mixed social and ecological outcomes. Percent for the positive, negative, and mixed outcomes is proportional to the total number of cases for social and ecological outcomes respectively, not the total sample.

\begin{tabular}{lcc}
\hline \hline & & Outcomes \\
\cline { 2 - 3 } & Social: cases (percent) & Ecological: cases (percent) \\
\hline Number of cases ${ }^{\dagger}$ & $56(86)$ & $18(28)$ \\
Positive outcomes & $19(34)$ & $14(78)$ \\
Negative outcomes & $26(46)$ & $2(11)$ \\
Mixed outcomes & $11(20)$ & $2(11)$ \\
\hline${ }^{\dagger}$ Includes the total number of cases that reported positive, negative, and mixed outcomes. Nine cases \\
assessed social and ecological outcomes.
\end{tabular}

Lapeyre 2010, Osano et al. 2013), while in others, scholarships were created by CBCs to enhance access to secondary and higher education (e.g., Glew et al. 2010, Silva and Mosimane 2014). Several CBCs disbursed meat to their members, which enhanced food security (e.g., Scanlon and Kull 2009, Collomb et al. 2010, Snyman 2012). Increased access to transportation services was provided for business purposes, as well as a means to support emergency transport services to medical facilities (e.g., Scanlon and Kull 2009, Glew et al. 2010, Sheppard et al. 2010, Dyer et al. 2014, Silva and Mosimane 2014). Additionally, training and extension support opportunities were provided, which helped CBC members acquire new skills (Lapeyre 2010, Gandiwa et al. 2013, Dyer et al. 2014). Although security was not addressed in many cases, it was an extremely important driver and a result of CBCs established in areas of historically high conflict zones and/ or areas of contested boundaries (e.g., Glew et al. 2010, Greiner 2012).

Fig. 6. Percent of cases that reported positive and negative social outcomes. Total number of cases assessed was 45 (11 cases that reported mixed positive and negative outcomes were removed from this analysis). Counts in the bar graph represent the number of cases.

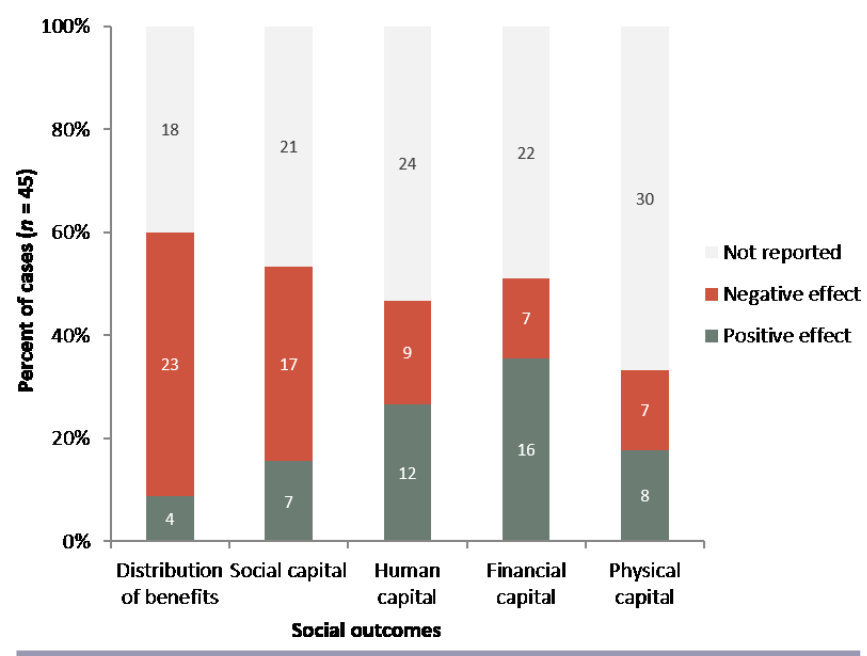

Several of the cases also reported positive social outcomes with respect to enhanced physical and social capital (Fig. 6). Enhanced physical capital outcomes included the construction of boreholes, roads, health clinics, improved electrification in community buildings and households, and enhanced infrastructure for irrigation of local crops (e.g., Scanlon and Kull 2009, Sheppard et al. 2010, Gandiwa et al. 2013, Dyer et al. 2014). For example, at the Kamoa Sustainable Livelihoods Programme, Democratic Republic of the Congo, a treadle pump was constructed to increase productivity of local crops and reduce farmer workload (Dyer et al. 2014). In some cases, these physical capital benefits further supported enhanced ecotourism opportunities, which in turn increased financial revenue streams. For example, the development of boreholes in the Wechiau Community Hippo Sanctuary, Ghana spurred a solar lighting initiative, which led to the establishment of a self-sustaining shea nut cooperative and increased visitation from ecotourists (Sheppard et al. 2010).

Positive social capital benefits included those associated with the maintenance and enhancement of networks, relationships of trust, reciprocity and exchange, and increased sense of ownership among CBC members for conservation-oriented projects. Community-based conservation institutions that fostered inclusive participation in decision-making processes helped build trust and support conflict resolution (Sheppard et al. 2010, Greiner 2012, Dyer et al. 2014). Further, CBCs enhanced reciprocity, exchange, and ownership (Glew et al. 2010, Snyman 2012, Dyer et al. 2014). For example, financial benefits received by members of West Gate Conservancy, Kenya allowed for greater participation in gift-giving and loan disbursements to family and friends (Glew et al. 2010). Community-based conservation institutions also helped maintain existing networks and create new ones (Lapeyre 2010, Snyman 2012). For example, the added benefits of employment opportunities in places where such opportunities were otherwise scarce allowed members of Torra Conservancy, Namibia to stay and maintain close family ties and extended networks, and to continue farming both for the livelihood and socio-cultural benefits it provided (Snyman 2012).

The most commonly reported negative social outcomes were the unequal distribution of benefits to $\mathrm{CBC}$ members and households (Fig. 6). In some cases, the unequal distribution of benefits was due in part to the relatively scarce benefits available to members, such that only a small percentage of $\mathrm{CBC}$ members (e.g., those directly employed at the $\mathrm{CBC}$ ) actually received any 
benefits (e.g., Wainwright and Wehrmeyer 1998, Suich 2013, Silva and Mosimane 2014). Yet, elite capture, where local and extralocal elites received a disproportionate percentage of benefits and engaged in exclusionary membership practices, was a major factor in the unequal distribution of benefits within CBCs (e.g., Wainwright and Wehrmeyer 1998, Songorwa 1999, Collomb et al. 2010, Hoole 2010, Kamoto et al. 2013, Silva and Mosimane 2014, Silva and Motzer 2015). This can happen in a number of ways. For instance, Zambia's ADMADE program initially reached out to local chiefs as the traditional authorities in Game Management Areas as a way to bridge the divide between the national-level Wildlife Department and local residents with respect to views on wildlife rights. In doing so, ADMADE provided chiefs with authority to chair the Wildlife Management subauthority and appoint members, and to select the individuals who would be trained and employed as village scouts. This quickly led to chiefs securing more power and wealth for themselves at the expense of local communities; for instance, representation on subauthority was reserved for relatives and those who were loyal to the chiefs, as were most salaried positions, and chiefs controlled what development projects to approve and where to approve them (Gibson and Marks 1995). In the case of land-based payment schemes, such as in Maasai Mara, Kenya, local elites who owned land were the only beneficiaries of payments for conservation at the expense of the landless, who were the poorest individuals that disproportionately bore the burden of these interventions (e.g., Bedelian 2012). Elite capture, and the unequal distribution of benefits was in a large part related to, and impacted, negative social, human, financial, and physical capital outcomes, some of which are discussed briefly.

Most cases that reported negative social outcomes also reported reductions in social capital. This occurred in the context of eroding community trust, changes to and reduction of traditional rules of use, and breakdowns in traditional networks and institutions (e.g., Songorwa 1999, Balint and Mashinya 2006, Jayne et al. 2009, Kamoto et al. 2013, Suich 2013, Dyer et al. 2014, Silva and Motzer 2015). For instance, in Malawi, Forestry Assistants were hired by the Forestry Department to enforce the 1996 Forest Policy in local Village Forest Areas. Yet, in Chindima Village Forest Area, the Forestry Assistant asked community leaders to mobilize members to start a tree nursery and promised that the Forestry Department would pay for materials. It was later discovered that the Forestry Assistant took the materials for himself, and later was accused of embezzling money. Both actions eroded community trust and reduced the likelihood of communities taking part in future projects (Kamoto et al. 2013). In other cases, $\mathrm{CBC}$ resulted in changes to, and reduction of, traditional rules of use and loss of cultural sites of importance. For example, the creation of the Golini-Mwaluganje Elephant Sanctuary, Kenya, removed local access to traditional Kaya forests (Mburu and Birner 2007). In some cases, such as those that were part of the ADMADE program, village scouts were hired to enforce rules and sanctions in Game Management Areas. However, in the case of Munyamadzi, Zambia, many of the scouts were young men, which conflicted with traditional institutional and elder authority, and therefore undermined social cohesion (Gibson and Marks 1995).

Negative human capital outcomes included reductions in security, access to education, health, and nutrition (Songorwa 1999, Greiner 2012, Kamoto et al. 2013, Gandiwa et al. 2013). For instance, the Ltungai Conservancy, Kenya, was established on contested lands of two historically warring tribes, the Pokot and Samburu. Yet, the Pokot were never advised that their neighbors had applied for conservancy status, and after the CBC was officially established, conflict and raids ensued (Greiner 2012). Also, one unintended consequence of CBCs was the resulting increase in human-wildlife conflicts, which in several cases has led to increased crop damage and reduced access to food (Songorwa 1999, Marks 2001, Gandiwa et al. 2013). In these cases, the costs associated with $\mathrm{CBC}$ outweighed any benefits. At Munyamadzi Game Reserve, Zambia, increased sanctions and enforcement limited traditional wildlife hunting practices inside the $\mathrm{CBC}$, which led to reduced access to meat protein (Marks 2001).

\section{Ecological outcomes}

Cases that reported positive ecological outcomes were related largely to components (e.g., biotic and abiotic factors) and relationships (e.g., ecosystem processes) (Fig. 7). Components measured were typically wildlife species, while relationships described were in reference to measures of biomass/productivity over time and nutrient cycling (see Appendix 1 for descriptions of ecological outcomes). Sheppard et al. (2010) described how the development of the Wechiau Community Hippo Sanctuary, Ghana, has led to the stabilization of an imperiled hippopotamus population in the region, while the establishment of Torra Conservancy, Namibia, led to increased wildlife populations as a function of reduced commercial poaching (Scanlon and Kull 2009). Glew et al. (2010) used remote sensing to illustrate how the development of conservation core areas with seasonal grazing zones has led to increased productivity, leaf litter accumulation, and maintenance of soil nutrient content when compared to ecologically matched nonconserved areas. Further, in Naibunga Conservancy, Kenya, conserved areas had significantly higher productivity and improved soil nutrient status, as indicated by enhanced carbon and nitrogen content, when compared to grazed, nonconserved areas (Mureithi et al. 2016).

Fig. 7. Percent of cases that reported positive and negative ecological outcomes. The total number of cases assessed was 16 (two cases that reported mixed positive and negative outcomes were removed from this analysis). Counts in the bar graph represent the number of cases.

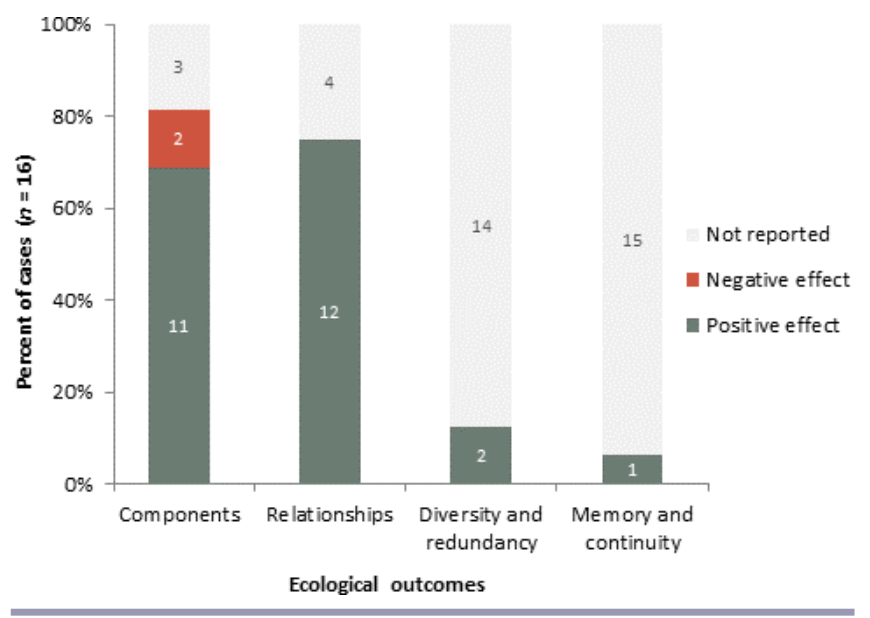


Fig. 8. Association between the institutional processes, or conditions, and outcomes. Social and ecological outcomes were pooled (no case reported positive social and negative ecological outcomes, or vice versa). The total number of cases included in this analysis was 54 (65 total cases minus 11 cases with mixed outcomes). The Fisher exact test was used to test the null hypothesis that there was no association between each condition and outcome. Asterisks denote conditions with low sample size that precluded test of association. Five conditions were significantly associated with reported outcomes: (1) nonmonetary incentives $(p=0),(2)$ monetary incentives $(p=0.001)$, (3) devolution of rights $(p<0.01)$, (4) collaboration $(p<0.001)$, and (5) cultural worldviews considered in the model $(p=0)$. Counts in the bar graph represent the number of cases.

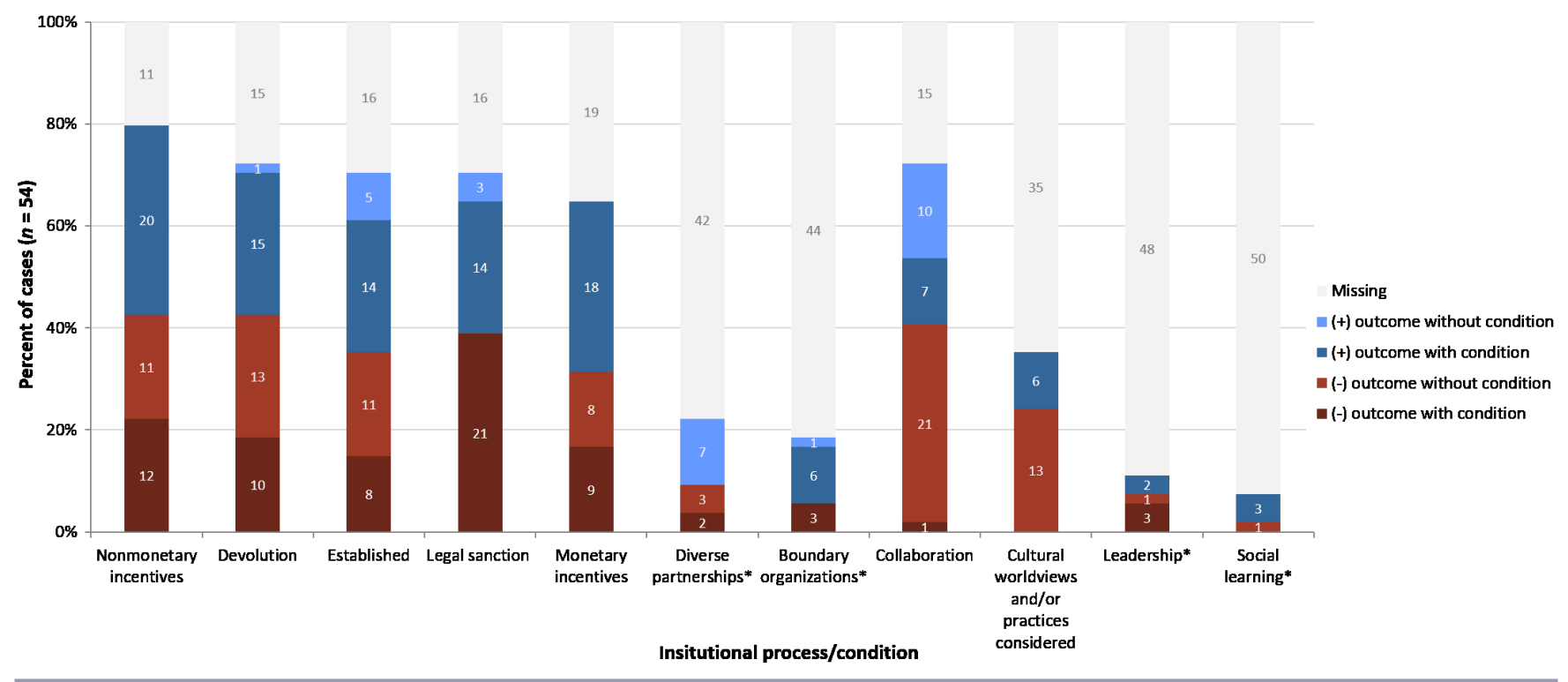

Enhanced diversity and redundancy was reported in two cases: Mureithi et al. (2016) found positive outcomes in plant diversity and redundancy when compared to nonconserved areas in Naibunga Conservancy, Kenya, while Sheppard et al. (2010) illustrated increases in bird diversity in Wechiau Community Hippo Sanctuary, Ghana, when compared to matched, adjacent nonconserved areas. Only two cases, both of which come from the same case study, found that $\mathrm{CBC}$ led to a decrease in wildlife species (i.e., components). Gibson and Marks (1995) and Marks (2001) found that hunting regulations and enforcement in the Munyamadzi Game Reserve, Zambia, reduced the killing of large mammals (e.g., elephants and rhinos), but in doing so, shifted hunting targets to smaller game by using less conspicuous hunting methods (e.g., snaring), and resulted in drastic reductions in those wildlife populations.

\section{Association between institutional processes and outcomes}

Fig. 8 illustrates the subset of institutional processes, or conditions, assessed in this review with respect to the number of cases that reported each condition, the number of cases that reported the presence and absence of the condition, and the association between each condition and case outcome. A number of variables were not accounted for in most cases, including leadership, social learning, consideration of cultural worldviews, and diverse partnerships. The results are limited to the five conditions found to be significantly associated with case outcomes.

Nonmonetary incentives and monetary incentives offered by the $\mathrm{CBC}$, which included human, physical, and social capital assets, and financial assets, respectively, were reported as present in all positive cases (Scanlon and Kull 2009, Sheppard et al. 2010, Glew et al. 2010, Dyer et al. 2014). However, the trend for negative outcomes was not as clear cut, which suggests that the presence of these incentives is important but not sufficient on their own for CBC success. Similarly, devolution of rights was significantly associated with case outcomes; most positive cases reported that rights had been devolved to the local community, at least in some capacity (e.g., Laperye 2010, Glew et al. 2010, Silva and Mosimane 2014). It is important to note that although devolution is a defining principle of CBCs, 14 of 39 cases (36\%) suggested that this is not occurring on the ground. For example, the Selous Conservation Programme, Tanzania, was originally designed to devolve authority and responsibility to local communities, yet the establishment of Jumuiya ya Kuhifadhi Maliasili Ukutu created an extra bureaucratic layer, similar to that of Zimbabwe's CAMPFIRE program, that effectively made decisions on behalf of local communities and did not serve their interests (Songorwa 1999). Similarly, in Malawi, the national government instituted the Forest Policy Act in 1997, which intended to devolve rights and authority regarding forest management to local Village Forest Areas through Village Natural Resource Management Committees, yet few Village Natural Resource Management Committees were actually given authority to manage and enforce rules in forest governance because all actions had to be approved by the national-level minister (Kamoto et al. 2013).

Most cases reported the absence of collaboration ( 31 of $39 ; 79 \%$ ). Collaboration did not occur due to inequity in decision-making and participation in management decisions, corruption, and 
nontransparent management practices from CBC members and other leaders (e.g., Gibson and Marks 1995, Kamoto et al. 2013, Silva and Motzer 2015). Only one case reported a negative outcome with collaboration present; in this case, there was a high degree of accountability, transparency, and information transfer between the $\mathrm{CBC}$ and households, yet few benefits of the $\mathrm{CBC}$ were provided to local members (Collomb et al. 2010).

Fewer cases reported on the extent to which cultural worldviews and/or traditional practices were considered in the CBC model. However, of those that did, there was a perfect association between the condition and outcomes. In other words, all cases that explicitly reported cultural worldviews were not considered to have negative outcomes, while each case that reported cultural worldviews was considered to have positive outcomes (e.g. Marks 2001, Sheppard et al. 2010, Greiner 2012, Dyer et al. 2014). For example, Marks (2001) illustrated how the traditional practices and social relations associated with hunting wildlife in the Luangwa valley, Zamibia, were not reducible to the economic incentives offered to limit hunting off-takes by the ADMADE program, and the rules imposed to curb poaching led only to a conversion in the types of species that were taken, which resulted in reduced ecological components (wildlife) and social outcomes. On the other hand, an exemplary case of conservation that considered the cultural practices and livelihoods of local communities was that of Ghana's Wechiau Community Hippo Sanctuary, where the conservation of imperiled hippopotami was successful in part due to local and cultural taboos against killing the species (Sheppard et al. 2010). Another example of a positive outcome that considered cultural worldviews/practices was that of the Kamoa and Nhambita CBCs in Democratic Republic of the Congo and Mozambique, respectively, which allowed for the integration of local agricultural and environmental knowledge systems with technical expertise to identify suitable agricultural sites and sustainable planting practices (Dyer et al. 2014).

\section{DISCUSSION}

This study provides the first systematic review of CBCs across sub-Saharan Africa. We reviewed the state of social and ecological outcomes, reviewed the extent to which institutional processes/ conditions were included in case studies, and tested the association between institutional conditions and social-ecological outcomes. Critical reflection is necessary to improve the goals of the $\mathrm{CBC}$ institutional model, and our efforts reveal the mixed nature of outcomes and substantial gaps in the existing research. Community-based conservation institutions, in general, have not consistently produced positive outcomes in Africa. More often than not the establishment of CBCs in Africa has led to negative or a mixture of positive and negative social outcomes, whereas ecological outcomes have been largely positive. This corroborates earlier regional findings of Campbell and Shackleton (2001), who evaluated 27 CBNRM cases in Southern Africa and found that "success" (i.e., sustainable management of natural resources) was at best relative but also rare. Our work also supports some of Brooks et al.'s (2012) global assessment of CBCs - specifically, that supportive cultural beliefs and institutions were found to be important for project success. However, their results suggest that $\mathrm{CBC}$ is, in general, a more effective approach because they found more successes than failures across all outcomes and more evidence for synergies than trade-offs between pairs of outcomes.
A clear gap in this field of inquiry exists pertaining to the type of data collected and the research focus, which has been overwhelmingly targeted to social outcomes, using qualitative methods. Most positive social outcomes reported enhanced financial capital and human capital, while negative social outcomes reported an unequal distribution of benefits to $\mathrm{CBC}$ households due to elite capture at the local and broader level, and a breakdown of social capital. There are relatively few studies of ecological outcomes, though most reported positive outcomes. The scarcity of ecological research in CBCs may be because biodiversity and its conservation have long been studied in more "natural" settings such as national parks and other protected areas that do not accommodate people. Yet, increasingly, scholars are making the case that it is precisely in CBCs where biodiversity will remain (e.g., Ogutu et al. 2017). Thus, there is an urgent need for increased research, and evaluation of both social and ecological outcomes in CBC.

Moreover, a number of important institutional processes that have been considered important components of CBC success were missing from consideration across most cases. This includes leadership, social learning, consideration of cultural worldviews, and diverse partnerships. Our analyses revealed that monetary and nonmonetary incentives are important but not sufficient on their own for positive outcomes. Most cases that reported positive outcomes also reported that rights were devolved to the local community. Yet, it is important to note that devolution did not occur in a number of cases, despite this feature being a hallmark of CBC. The consideration of cultural practices and traditional livelihoods was not well reported but was significantly associated with positive outcomes. A lack of collaboration due to inequity in decision-making and participation, and corruption continues to hinder CBC goals. However, Collomb et al. (2010) argue that good governance alone may not be sufficient to provide substantial benefits and set CBC initiatives on a self-reliant development path. That goal is also partially constrained by $\mathrm{CBC}$ management actions and the ways in which they are mediated and managed from several spatial and social scales (Cumming et al. 2015).

Interpretation of these results must be made with a measure of caution because our findings are inherently confined to the data at our disposal. Published studies were lacking in some regions, including few studies in West and Central Africa and none in North Africa. This may be a result of our searches being limited to English-language journals, which potentially resulted in a number of applicable cases reported in French-, Portuguese-, and Spanish-language journals (e.g., Equatorial Guinea) being overlooked. Thus, expanding search efforts to include these sources is an important next step. However, this may also be the result of distinctions in land tenure arrangements across regions. Government recognition of CBC institutions and more clearly defined local land rights are present in many East and Southern African countries when compared to Central Africa, where codified tenure arrangements are ill-defined, spatially varied within a single country (e.g., Democratic Republic of the Congo), or nonexistent. Further, even though many of the cases did not report on institutional processes, this does not necessarily mean that these processes were not occurring, just that they were not addressed in the research at our disposal. Despite these limitations, the analyses reported here provide initial insights into 
CBC institutions and further offer a road map moving forward. The combination of differences in data collection methods across cases, the disproportionate focus on social outcomes, and the high number of missing data on institutional processes proposed by the literature as important for CBC success all suggest a need for a more research, and specifically, a systematized research design strategy that provides a framework for evaluation at the local level, and synthesis across CBCs in Africa.

\section{CONCLUSIONS}

Each $\mathrm{CBC}$ case was evaluated within a common framework to organize the findings and to identify gaps of knowledge. Through the analysis we have added knowledge to a theory of CBC (Ostrom 2007, 2009) that can help guide social-ecological interactions toward sustainable trajectories, which is the primary goal of CBCs (Ostrom 2007). The framework provides several issues for consideration. First, CBC research gaps are likely a function of the absence of a coherent framework for data collection as well as limited monitoring and evaluation efforts. The framework we presented offers a useful starting point to structure systematic research and evaluation of $\mathrm{CBC}$ through consideration of regional to global social and ecological settings, with consideration of local institutional arrangements and governance processes, and the resulting outcomes. We found gaps both in social and ecological outcomes and in the processes or conditions that are theoretically important to the outcomes. As we mention, however, these is only a small set of variables to consider; flexibility is needed to attend to the myriad and place-based factors that impact $\mathrm{CBC}$ successes and failures, and to ensure that assessments are locally desirable and plausible.

Second, consideration of broader social-ecological and economic conditions is critical for understanding the social and ecological outcomes of CBCs and assessing their sustainability. While this analysis has addressed ecological and social processes and outcomes at the local scale, ecological, social, political, and economic processes at broader scales are dominant shaping forces on the local scale and are therefore integral to any analysis (Cumming 2016). For instance, which wildlife assemblages can occur in a local place and the relative carrying capacity is in part limited by elevation and precipitation, and therefore cannot be changed by management, which has implications for tourist visitation and for the amount of social outcomes that can be expected (e.g., Naidoo et al. 2011). Also, CBCs are vulnerable to social and ecological shocks. For instance, although the Wechiau Community Hippo Sanctuary is a good case of CBC success, ecotourism revenues are in large part dependent on the conservation of an imperiled species. Recent hydroelectric development downstream from the sanctuary could impact grazing habitat, increase the potential for poaching, and reduce connectivity to the only other surviving hippo population in Ghana. These issues, coupled with increases in the severity and frequency of drought, will further stress the hippo population (Shepphard et al. 2010). Further, shocks of national economic decline and political crisis coupled with the withdrawal of outside donors due to land reforms can alter $\mathrm{CBC}$ operations and trajectories, further reinforcing the problematic nature of onesize-fits-all approaches and revenue production focused solely on tourism. For example, in the wake of the Westgate Mall attack by the violent extremist organization Al Shabab in Nairobi, Kenya in 2013 and a subsequent increase in similar attacks, conservation- based tourism in Kenya has taken a major hit, with estimates of a 25\% drop in visitor numbers for 2015 (Morris 2015). Institutional partnerships are varied, occur at the local to global levels, and change through time, highlighting the importance of changing networks in the evolution of commons institutions (Seixas and Berkes 2010).

Clearly, there are several different institutional models and configurations of conservation from people-free protected areas to "social conservation" (Miller et al. 2011). We have used the definition of CBC institutional goals of supporting both positive social and ecological outcomes. Given this view, our results suggest that if conservation is combined with enhanced human well-being, then there needs to be more recognition of local people's worldviews, power dynamics, and networks in the process of institution building. Further, CBCs need more work in monitoring ecological outcomes. This may lead to greater positive social outcomes but may also lead to a better understanding of the circumstances under which development conflicts with conservation goals, thus contributing to what Miller et al. (2011) state as a "complex matrix of trade-offs."

Like other institutional prescriptions, $\mathrm{CBCs}$ should not be viewed as a panacea (Ostrom and Cox 2010); rather, governance approaches should support a level of flexibility and adaptability that spans institutional and ecological scales, which in turn extends to the ways in which CBCs are evaluated over time. At the local scale, scholars have argued that rigid adherence to community resource management and development templates, based on features that include spatially delimiting appropriate land uses, strengthening community exclusionary powers, and clarifying specific claims to village resources, actually run the risk of increasing local ecological and economic vulnerabilities. This is seen in the African context, with resource access issues faced between transhumant pastoralists and sedentary agriculturalists at regional scales in countries such as Mali, Niger, and Cameroon (Turner 1999, Moritz et al. 2013, Turner et al. 2016). While individual CBCs comprised the cases for this review, due to increasing land fragmentation caused by many forces (Galvin et al. 2008), many CBCs are joining together to create contiguous landscapes for biodiversity and people. The Northern Rangelands Trust, Kenya (http://www.nrt-kenya.org/), for example, is a group of more than $30 \mathrm{CBCs}$. These landscape-level groups may become more important as projected trends in climate and environmental changes force different stresses on these systems. How these new approaches affect social and ecological outcomes is unknown but needs to be investigated.

Nevertheless, each $\mathrm{CBC}$ institution is distinct and will require individualized attention regarding its specific conservation and livelihood activities, identification of social and ecological assets and vulnerabilities, appropriate governance structures, and economic development models to ensure long-term sustainability. Still, we argue that there needs to be a concerted effort to develop relevant and inclusive frameworks that enable synthesis and lessons learned across cases and contexts. The variables outlined in Fig. 1 and Appendix 1 offer a starting point to evaluate the contribution $\mathrm{CBC}$ institutions are making to social and ecological improvements in Africa, and to provide feedback for adaptive learning through negotiating and renegotiating the process to identify where improvements are needed. This is critical for these 
institutions, which rest within a diverse mosaic of protected area forms, to demonstrate their effectiveness and value to maintain political, economic, and social support (Cumming 2016).

[1]“Public-public" is a CBC management arrangement involving the government or state on public or communally owned land; "public-private" is a CBC management arrangement involving communities and private industry (e.g., tourism companies and often the government at some capacity) on public or communally owned land; and "private-private" is a CBC management arrangement involving communities and the private sector on privately owned land.

Responses to this article can be read online at: http://www.ecologyandsociety.org/issues/responses. php/10217

\section{Acknowledgments:}

Partial funding came from the Africa Center at Colorado State University (http:/lafricacenter.colostate.edul). We are grateful to Steve Chignell for his help in drafting some of the figures and to Emily Orlikoff for editorial help.

\section{LITERATURE CITED}

Agrawal, A. 2001. Common property institutions and sustainable governance of resources. World Development 29(10):1649-1672. http://dx.doi.org/10.1016/S0305-750X(01)00063-8

Agrawal, A. 2003. Sustainable governance of common-pool resources: context, methods, and politics. Annual Review of Anthropology 32(1):243-262. http://dx.doi.org/10.1146/annurev. anthro.32.061002.093112

Agrawal, A., and K. Redford. 2009. Conservation and displacement: an overview. Conservation \& Society 7(1):1-10. http://dx.doi.org/10.4103/0972-4923.54790

Andersson, K. P., and E. Ostrom. 2008. Analyzing decentralized resource regimes from a polycentric perspective. Policy Sciences 41(1):71-93. http://dx.doi.org/10.1007/s11077-007-9055-6

Armitage, D. 2005. Adaptive capacity and community-based natural resource management. Environmental Management 35 (6):703-715. http://dx.doi.org/10.1007/s00267-004-0076-Z

Armitage, D. R., R. Plummer, F. Berkes, R. I. Arthur, A. T. Charles, I. J. Davidson-Hunt, A. P. Diduck, N. C. Doubleday, D. S. Johnson, M. Marschke, P. McConney, E. W. Pinkerton, and E. K. Wollenberg. 2009. Adaptive co-management for socialecological complexity. Frontiers in Ecology and the Environment 7(2):95-102. http://dx.doi.org/10.1890/070089

Awung, N. S., and R. Marchant. 2016. Investigating the role of the local community as co-managers of the Mount Cameroon National Park Conservation project. Environments 3(4):36. http:// dx.doi.org/10.3390/environments3040036

Baival, B., and M. Fernández-Giménez. 2012. Meaningful learning for resilience-building among Mongolian pastoralists. Nomadic Peoples 16(2):53-77. http://dx.doi.org/10.3167/np.2012.160205
Balint, P. J., and J. Mashinya. 2006. The decline of a model community-based conservation project: governance, capacity, and devolution in Mahenye, Zimbabwe. Geoforum 37(5):805-815. http://dx.doi.org/10.1016/j.geoforum.2005.01.011

Barrett, C. B., A. J. Travis, and P. Dasgupta. 2011. On biodiversity conservation and poverty traps. Proceedings of the National Academy of Sciences of the United States of America 108 (34):13907-13912. http://dx.doi.org/10.1073/pnas.1011521108

Bedelian, C. 2012. Conservation and ecotourism on privatised land in the Mara, Kenya: the case of conservancy land leases. LDPI Working Paper 9. Land Deal Politics Initiative. http://r4d.dfid. gov.uk/PDF/Outputs/Futureagriculture/LDPI-09-bedelian 0.pdf

Bedelian, C. E. 2014. Conservation, tourism and pastoral livelihoods: wildlife conservancies in the Maasai Mara, Kenya. Dissertation. University College London, London, UK.

Berkes, F. 2004. Rethinking community-based conservation. Conservation Biology 18(3):621-630. http://dx.doi.org/10.1111/ j.1523-1739.2004.00077.x

Berkes, F. 2007. Community-based conservation in a globalized world. Proceedings of the National Academy of Sciences of the United States of America 104(39):15188-15193. http://dx.doi. org/10.1073/pnas.0702098104

Berkes, F. 2009. Evolution of co-management: role of knowledge generation, bridging organizations and social learning. Journal of Environmental Management 90(5):1692-1702. http://dx.doi. org/10.1016/j.jenvman.2008.12.001

Berrang-Ford, L., T. Pearce, and J. D. Ford. 2015. Systematic review approaches for climate change adaptation research. Regional Environmental Change 15(5):755-769. http://dx.doi. org/10.1007/s10113-014-0708-7

Black, R., and P. B. Cobbinah. 2017. On the rim of inspiration: performance of AWF tourism enterprises in Botswana and Rwanda. Journal of Sustainable Tourism 25(11):1600-1616. http:// dx.doi.org/10.1080/09669582.2017.1296454

Blaikie, P. 2006. Is small really beautiful? Community-based natural resource management in Malawi and Botswana. World Development 34(11):1942-1957. http://dx.doi.org/10.1016/j. worlddev.2005.11.023

Bray, N., I. Dubchak, and J. Pachter. 2003. AVID: a global alignment program. Genome Research 13(1):97-102. http://dx.doi. org/10.1101/gr.789803

Brooks, J. S., K. A. Waylen, and M. Borgerhoff Mulder. 2012. How national context, project design, and local community characteristics influence success in community-based conservation projects. Proceedings of the National Academy of Sciences of the United States of America 109:21265-21270. http://dx.doi. org/10.1073/pnas.1207141110

Campbell, B., and S. Shackleton. 2001. The organizational structures for community-based natural resource management in Southern Africa. African Studies Quarterly 5(3):87-114.

Chambers, R., and G. R. Conway. 1992. Sustainable rural livelihoods: practical concepts for the 21st century. Institute of Development Studies. 
Collomb, J. G. E., P. Mupeta, G. Barnes, and B. Child. 2010. Integrating governance and socioeconomic indicators to assess the performance of community-based natural resources management in Caprivi (Namibia). Environment Conservancy 37 (3):303-309. http://dx.doi.org/10.1017/S0376892910000676

Cumming, G. S. 2016. The relevance and resilience of protected areas in the Anthropocene. Anthropocene 13:46-56. http://dx.doi. org/10.1016/j.ancene.2016.03.003

Cumming, C., S. C. R. Allen, N. C. Ban, D. Biggs, H. C. Biggs, D. H. M. Cumming, A. De Vos, G. Epstein, M. Etienne, K. Maciejewski, et al. 2015. Understanding protected area resilience: a multi-scale, social-ecological approach. Ecological Applications 25(2):299-319. http://dx.doi.org/10.1890/13-2113.1

Department for International Development (DFID). 1999. Sustainable livelihoods guidance sheets. London, UK.

Díaz, S., S. Demissew, J. Carabias, C. Joly, M. Lonsdale, N. Ash, A. Larigauderie, J. R. Adhikari, S. Arico, A. Báldi, and A. Bartuska. 2015. The IPBES Conceptual Frameworkconnecting nature and people. Current Opinion in Environmental Sustainability 14:1-16.

Dougill, A. J., L. C. Stringer, J. Leventon, M. Riddell, H. Rueff, D. V. Spracklen, and E. Butt. 2012. Lessons from communitybased payment for ecosystem service schemes: from forests to rangelands. Philosophical Transactions of the Royal Society of London B: Biological Sciences 367(1606):3178-3190. http://dx. doi.org/10.1098/rstb.2011.0418

Duffy, R. 2006. The potential and pitfalls of global environmental governance: the politics of transfrontier conservation areas in Southern Africa. Political Geography 25(1):89-112. http://dx.doi. org/10.1016/j.polgeo.2005.08.001

Dyer, J., L. C. Stringer, A. J. Dougill, J. Leventon, M. Nshimbi, F. Chama, A. Kafwifwi, J. I. Muledi, J.-M. K. Kaumbu, M. Falcao, S. Muhorro, F. Munyemba, G. M. Kalaba, and S. Syampungani. 2014. Assessing participatory practices in community-based natural resource management: experiences in community engagement from southern Africa. Journal of Environmental Management 137:137-145. http://dx.doi.org/10.1016/ j.jenvman.2013.11.057

Fagerholm, N., M. Torralba, P. J. Burgess, and T. Plieninger. 2016. A systematic map of ecosystem services assessments around European agroforestry. Ecological Indicators 62:47-65. http://dx. doi.org/10.1016/j.ecolind.2015.11.016

Ford, J. D., L. Berrang-Ford, and J. Paterson. 2011. A systematic review of observed climate change adaptation in developed nations: a letter. Climatic Change 106:327-336. http://dx.doi. org/10.1007/s10584-011-0045-5

Ford, J. D. and T. Pearce. 2010. What we know, do not know, and need to know about climate change vulnerability in the western Canadian Arctic: a systematic literature review. Environmental Research Letters 5(1):014008. http://dx.doi.org/10.1088/1748-9326/5/1/014008

Galvin, K. A. 2009. Transitions: pastoralists living with change. Annual Review of Anthropology 38(1):185-198. http://dx.doi. org/10.1146/annurev-anthro-091908-164442
Galvin, K. A., R. S. Reid, R. H. Behnke Jr., and N. Thompson Hobbs, editors. 2008. Fragmentation of semi-arid and arid landscapes. consequences for human and natural systems. Springers, Dordrecht, The Netherlands. http://dx.doi. org/10.1007/978-1-4020-4906-4

Gavin, M., J. McCarter, A. Mead, F. Berkes, J. R. Stepp, D. Peterson, and R. Tang. 2015. Defining biocultural approaches to conservation. Trends in Ecology \& Evolution 30:140-145. http:// dx.doi.org/10.1016/j.tree.2014.12.005

Gandiwa, E., I. Heitkönig, A. Lokhorst, H. Prins, and C. Leeuwis. 2013. CAMPFIRE and human-wildlife conflicts in local communities bordering northern Gonarezhou National Park, Zimbabwe. Ecology and Society 18(4):7. http://dx.doi. org/10.5751/ES-05817-180407

Gibson, C. C. 1999. Politicians and poachers: the political economy of wildlife policy in Africa. Cambridge University Press. http://dx. doi.org/10.1017/CBO9780511625640

Gibson, C. C., and S. A. Marks. 1995. Transforming rural hunters into conservationists: an assessment of community-based wildlife management programs in Africa. World Development 23 (6):941-957. http://dx.doi.org/10.1016/0305-750X(95)00025-8

Glew, L. 2012. Evaluating the effectiveness of community-based conservation in northern Kenya. Dissertation. University of Southampton, Southampton, U.K.

Glew, L., M. D. Hudson, and P. E. Osborne. 2010. Evaluating the effectiveness of community-based conservation in northern Kenya: a report to The Nature Conservancy. Centre for Environmental Sciences, University of Southampton, Southampton, UK.

Goldman, M. J., and F. Riosmena. 2013. Adaptive capacity in Tanzanian Maasailand: changing strategies to cope with drought in fragmented landscapes. Global Environmental Change 23 (3):588-597. http://dx.doi.org/10.1016/j.gloenvcha.2013.02.010

Greiner, C. 2012. Unexpected consequences: wildlife conservation and territorial conflict in northern Kenya. Human Ecology 40(3):415-425. http://dx.doi.org/10.1007/s10745-012-9491-6

Haddaway, N. R., P. Woodcock, B. Macura, and A. Collins. 2015. Making literature reviews more reliable through application of lessons from systematic reviews. Conservation Biology 29 (6):1596-1605. http://dx.doi.org/10.1111/cobi.12541

Hansen, A. J., C. R. Davis, N. Piekielek, J. Gross, D. M. Theobald, S. Goetz, F. Melton, and R. DeFries. 2011. Delineating the ecosystems containing protected areas for monitoring and management. BioScience 61:363-373. http://dx.doi.org/10.1525/ bio.2011.61.5.5

Hoole, A. 2007. Lessons from the Equator Initiative: common property perspectives for community-based conservation in Southern Africa and Namibia. Centre for Community-Based Resource Management, Natural Resources Institute, University of Manitoba, Winnipeg, Manitoba, Canada.

Hoole, A. 2008. Community-based conservation and protected areas in Namibia: social-ecological linkages for biodiversity. Dissertation. University of Manitoba, Winnipeg, Manitoba, Canada. 
Hoole, A. 2010. Place-power-prognosis: community-based conservation, partnerships, and ecotourism enterprises in Namibia. International Journal of the Commons 4(1):78-99. http:// dx.doi.org/10.18352/ijc.112

Igoe, J. 2006. Measuring the costs and benefits of conservation to local communities. Journal of Ecological Anthropology 10:72-77. http://dx.doi.org/10.5038/2162-4593.10.1.7

Jayne, T. S., B. Zulu, G. Kajoba, and M. T. Weber. 2009. Access to land, and poverty reduction in rural Zambia: connecting the policy issues. Food Security Collaborative Policy Briefs 55054. Michigan State University, Department of Agricultural, Food, and Resource Economics, East Lansing, Michigan, USA. https:// ideas.repec.org/p/ags/midcpb/55054.html

Kamoto, J., G. Clarkson, P. Dorward, and D. Shepherd. 2013. Doing more harm than good? Community based natural resource management and the neglect of local institutions in policy development. Land Use Policy 35:293-301. http://dx.doi. org/10.1016/j.landusepol.2013.06.002

Kaplan-Hallam, M., and N. J. Bennett. 2017. Adaptive social impact management for conservation and environmental management. Conservation Biology 32:304-314. http://dx.doi. org/10.1111/cobi.12985

Kothari, A. 2006. Community conserved areas: towards ecological and livelihood security. Parks 16(1):3-13.

Lapeyre, R. 2010. Community-based tourism as a sustainable solution to maximise impacts locally? The Tsiseb Conservancy case, Namibia. Development Southern Africa 27:757-772. http:// dx.doi.org/10.1080/0376835X.2010.522837

Leisher, C., G. Temsah, F. Booker, M. Day, L. Samberg, D. Prosnitz, B. Agarwal, E. Matthews, D. Roe, D. Russell, T. Sunderland, and D. Wilkie. 2016. Does the gender composition of forest and fishery management groups affect resource governance and conservation outcomes? A systematic map. Environmental Evidence 5:6. https://doi.org/10.1186/s13750-016-0057-8

Mace, G. M. 2014. Whose conservation? Science 345 (6204):1558-1560. http://dx.doi.org/10.1126/science.1254704

Marks, S. A. 2001. Back to the future: some unintended consequences of Zambia's community-based wildlife program (ADMADE). Africa Today 48(1):121-141. http://dx.doi. org/10.2979/AFT.2001.48.1.120

Mathevet, R., J. D. Thompson, C. Folke, and F. S. Chapin III. 2016. Protected areas and their surrounding territory: socioecological systems in the context of ecological solidarity. Ecological Applications 26:5-16. http://dx.doi.org/10.1890/14-0421

Mburu, J., and R. Birner. 2007. Emergence, adoption, and implementation of collaborative wildlife management or wildlife partnerships in Kenya: a look at conditions for success. Society \& Natural Resources 20(5):379-395. http://dx.doi. org/10.1080/08941920701211645

McKinnon, M. C., S. H. Cheng, S. Dupre, J. Edmond, R. Garside, L. Glew, M. B. Holland, E. Levine, Y. J. Masuda, D. C. Miller, I. Oliveira, J. Revenaz, D. Roe, S. Shamer, D. Wilkie, S. Wongbusarakum, and E. Woodhouse. 2016. What are the effects of nature conservation on human well-being? A systematic map of empirical evidence from developing countries. Environmental Evidence 5(8):1-25. http://dx.doi.org/10.1186/s13750-016-0058-7

Miller, T. R., B. A. Minteer and L.-C. Malan. 2011. The new conservation debate: the view from practical ethics. Biological Conservation 144(3):948-957. http://dx.doi.org/10.1016/j. biocon.2010.04.001

Morgan-Brown, T., S. K. Jacobson, K. Wald, and B. Child. 2010. Quantitative assessment of a Tanzanian integrated conservation and development project involving butterfly farming. Conservation Biology 24(2):563-572. http://dx.doi.org/10.1111/ j.1523-1739.2009.01433.x

Moritz, M., B. L. Catherine, A. K. Drent, S. Kari, A. Mouhaman, and P. Scholte. 2013. Rangeland governance in an open system: protecting transhumance corridors in the Far North Province of Cameroon. Pastoralism: Research, Policy and Practice 3:26. http:// dx.doi.org/10.1186/2041-7136-3-26

Morris, H. 2015. Kenya visitor numbers fall 25 percent as terrorism hits tourism. The Telegraph, June 12, 2015. http://www. telegraph.co.uk/travel/destinations/africa/kenya/articles/Kenya-visitornumbers-fall-25-per-cent-as-terrorism-hits-tourism/

Morton, H., E. Winter, and U. Grote. 2016. Assessing natural resource management through integrated environmental and social-economic accounting: the case of a Namibian conservancy. Journal of Environment \& Development 25(4):396-425. http://dx. doi.org/10.1177/1070496516664385

Mureithi, S. M., A. Verdoodt, J. T. Njoka, C. K. K. Gachene, F. Warinwa, and E. Van Ranst. 2016. Impact of community conservation management on herbaceous layer and soil nutrients in a Kenyan semi-arid savannah. Land Degradation \& Development 27(8):1820-1830. http://dx.doi.org/10.1002/ldr.2315

Naidoo, R., G. Stuart-Hill, C. Weaver, J. Tagg, A. Davis, and A. Davidson. 2011. Effect of diversity of large wildlife species on financial benefits to local communities in northwest Namibia. Environmental and Resource Economics 48:321-335. http://dx.doi. org/10.1007/s10640-010-9412-3

Ogutu, J. O., B. Kuloba, H.-P. Piepho, and E. Kanga. 2017. Wildlife population dynamics in human-dominated landscapes under community-based conservation: the example of Nakuru Wildlife Conservancy, Kenya. PloS ONE 12(1):e0169730. http:// dx.doi.org/10.1371/journal.pone.0169730

Osano, P. M., M. Y. Said, J. de Leeuw, N. Ndiwa, D. Kaelo, S. Schomers, R. Birner, and J. O. Ogutu. 2013. Why keep lions instead of livestock? Assessing wildlife tourism-based payment for ecosystem services involving herders in the Maasai Mara, Kenya. Natural Resources Forum 37(4):242- 256. http://dx.doi. org/10.1111/1477-8947.12027

Ostrom, E. 1990. Governing the commons: the evolution of institutions for collective action. Cambridge University Press, Cambridge.

Ostrom, E. 2007. A diagnostic approach for going beyond panaceas. Proceedings of the National Academy of Sciences of the United States of America 104(39):15181-15187. http://dx.doi. org/10.1073/pnas.0702288104 
Ostrom, E. 2008. The challenge of common-pool resources. Environment: Science and Policy for Sustainable Development 50 (4):8-21. http://dx.doi.org/10.3200/ENVT.50.4.8-21

Ostrom, E. 2009. A general framework for analyzing sustainability of social-ecological systems. Science 325 (5939):419-422. http://dx.doi.org/10.1126/science.1172133

Ostrom, E., and M. Cox. 2010. Moving beyond panaceas: a multitiered diagnostic approach for social-ecological analysis. Environmental Conservation 37(04):451-463. http://dx.doi. org/10.1017/S0376892910000834

Ostrom, E., T. Dietz, N. Dolšak, P. C. Stern, S. Stonich, and E. U. Weber. 2002. The drama of the commons. National Academy Press.

Plummer, R., and D. Armitage. 2007. A resilience-based framework for evaluating adaptive co-management: linking ecology, economics and society in a complex world. Ecological Economics 61:62-74. http://dx.doi.org/10.1016/j.ecolecon.2006.09.025

Plummer, R., D. Armitage, and R. C. de Loë. 2013. Adaptive comanagement and its relationship to environmental governance. Ecology and Society 18(1):21. http://dx.doi.org/10.5751/ ES-05383-180121

Plummer, R., B. Crona, D. R. Armitage, P. Olsson, M. Tengö, and O. Yudina. 2012. Adaptive comanagement: a systematic review and analysis. Ecology and Society 17(3):11. http://dx.doi. org/10.5751/ES-04952-170311

Reid, R. S., M. E. Fernández-Giménez, and K. A. Galvin. 2014. Dynamics and resilience of rangelands and pastoral peoples around the globe. Annual Review Environment and Resources 39 (1):217-242. http://dx.doi.org/10.1146/annurev-environ-020713-163329

Ribot, J. C., J. F. Lund, and T. Treue. 2010. Democratic decentralization in sub-Saharan Africa: its contribution to forest management, livelihoods, and enfranchisement. Environmental Conservation 37(1):35-44. http://dx.doi.org/10.1017/S0376892910000329

Robinson, L. W., and F. Berkes. 2011. Multi-level participation for building adaptive capacity: formal agency-community interactions in northern Kenya. Global Environmental Change 21 (4):1185-1194. http://dx.doi.org/10.1016/j.gloenvcha.2011.07.012

Roe, D., F. Nelson, and C. Sandbrook, editors. 2009. Community management of natural resources in Africa: impacts, experiences and future directions. IIED, London, UK.

Scanlon, L. J., and C. A. Kull. 2009. Untangling the links between wildlife benefits and community-based conservation at Torra Conservancy, Namibia. Development Southern Africa 26 (1):75-93. http://dx.doi.org/10.1080/03768350802640107

Scoones, I. 1998. Sustainable rural livelihoods: a framework for analysis. IDS Working Paper 72. Institute of Development Studies. https://www.ids.ac.uk/publication/sustainable-rural-livelihoodsa-framework-for-analysis

Seixas, C. S., and F. Berkes. 2010. Community-based enterprises: the significance of partnerships and institutional linkages. International Journal of the Commons 4(1):183-212. http://dx.doi. org/10.18352/ijc. 133
Seixas, C. S., and B. Davy. 2008. Self-organization in integrated conservation and development initiatives. International Journal of the Commons 2(1):99-125. http://dx.doi.org/10.18352/ijc.24

Seixas, C. S., C. V. Minte-Vera, R. G. Ferreira, R. L. Moura, I. B. Curado, J. Pezzuti, P. G. Ana, and R. R. Francini-Filho. 2009. Co-managing commons: advancing aquatic resources management in Brazil. Current Trends in Human Ecology 156(182):156-182. http://dx.doi.org/10.5848/CSP.0441.00007

Sheppard, D. J., A. Moehrenschlager, J. M. Mcpherson, and J. J. Mason. 2010. Ten years of adaptive community-governed conservation: evaluating biodiversity protection and poverty alleviation in a West African hippopotamus reserve. Environmental Conservation 37:270-282. http://dx.doi.org/10.1017/ $\underline{\mathrm{S} 037689291000041 \mathrm{X}}$

Silva, J., and A. Mosimane. 2014. "How could I live here and not be a member?": economic versus social drivers of participation in Namibian conservation programs. Human Ecology 42 (2):183-197. http://dx.doi.org/10.1007/s10745-014-9645-9

Silva, J., and N. Motzer. 2015. Hybrid uptakes of neoliberal conservation in Namibian tourism-based development. Development and Change 46(1):48-71. http://dx.doi.org/10.1111/ dech.12139

Snyman, S. 2012. Ecotourism joint ventures between the private sector and communities: an updated analysis of the Torra Conservancy and Damaraland Camp partnership, Namibia. Tourism Management Perspectives 4:127-135. http://dx.doi. org/10.1016/j.tmp.2012.07.004

Songorwa, A. N. 1999. Community-based wildlife management (CWM) in Tanzania: Are the communities interested? World Development 27(12):2061-2079. http://dx.doi.org/10.1016/S0305-750X (99)00103-5

Songorwa, A., T. Buhrs, and K. Hughey. 2000. Community-based wildlife management in Africa: a critical assessment of the literature. Natural Resources Journal 40:603.

Suich, H. 2010. The livelihood impacts of the Namibian community based natural resource management programme: a meta-synthesis. Environmental Conservation 37(1):45-53. http:// dx.doi.org/10.1017/S0376892910000202

Suich, H. 2013. Evaluating the household level outcomes of community based natural resource management: the Tchuma Tchato Project and Kwandu Conservancy. Ecology and Society 18(4):25. http://dx.doi.org/10.5751/ES-05875-180425

Taylor, R. 2009. Community based natural resource management in Zimbabwe: the experience of CAMPFIRE. Biodiversity Conservation 18:2563-2583. http://dx.doi.org/10.1007/s10531-009-9612-8

Tengö, M., E. S. Brondizio, T. Elmqvist, P. Malmer, and M. Spierenburg. 2014. Connecting diverse knowledge systems for enhanced ecosystem governance: the multiple evidence base approach. Ambio 43(5):579-591. http://dx.doi.org/10.1007/ $\underline{\mathrm{s} 13280-014-0501-3}$

Tinsley, H. E. A., and D. J. Weiss. 2000. Interrater reliability and agreement. Pages 95-124 in H. E. A. Tinsley and S. Brown, editors. Handbook of applied multivariate statistics and mathematical modeling. First edition. Academic Press. 
Turner, M. D. 1999. Conflict, environmental change, and social institutions in dryland Africa: limitations of the community resource management approach. Society \& Natural Resources 12 (7):643-657. http://dx.doi.org/10.1080/089419299279362

Turner, M. D., J. G. McPeak, K. Gillin, E. Kitchell, and N. Kimambo. 2016. Reconciling flexibility and tenure security for pastoral resources: the geography of transhumance networks in eastern Senegal. Human Ecology 44:199-215. http://dx.doi. org/10.1007/s10745-016-9812-2

Upton, C. 2012. Adaptive capacity and institutional evolution in contemporary pastoral societies. Applied Geography 33 (1):135-141. http://dx.doi.org/10.1016/j.apgeog.2011.10.008

Waddington, H., H. White, B. Snilstveit, J. Hombrados, M. Vojtkova, P. Davies, A. Bhavsar, J. Eyers, T. Koehlmoos, M. Petticrew, and J. Valentine. 2012. How to do a good systematic review of effects in international development: a tool kit. Journal of Development Effectiveness 4(3):359-387. http://dx.doi. org/10.1080/19439342.2012.711765

Wainwright, C., and W. Wehrmeyer. 1998. Success in integrating conservation and development? A study from Zambia. World Development 26(6):933-944. http://dx.doi.org/10.1016/S0305-750X (98)00027-8

Western, M., and E. O. Wright. 1994. The permeability of class boundaries to intergenerational mobility among men in the United States, Canada, Norway and Sweden. American Sociological Review 59(4):606-629. http://dx.doi.org/10.2307/2095934 


\section{Appendix 1: Definitions of institutional process and outcome variables used in review}

Below, we provide additional information on the institutional processes, or conditions, and social and ecological outcomes used in this review. We include definitions of each of the concepts with examples and sources from the literature, and the criteria for how each was coded. The inclusion and exclusion criteria for each of the institutional processes were first identified and defined deductively from the literature and further refined using an iterative and collaborative process of individual and joint coding of the cases in the review. The coding structure also was used to isolate segments of text that reported social and ecological outcomes. These codes and concepts were developed based on the sustainable livelihoods framework and ecology parameters as defined by Plummer and Armitage (2007) and DfID (1999). Each case was read in entirety and coded for institutional processes as present, absent, or missing (1, 0, and n/a, respectively). Outcomes were coded as positive, negative, mixed, or missing (1, 0, mixed, and n/a, respectively). The "absence" of any variable was only coded as such if reported as absent; variables that were not reported in each case were coded n/a, i.e., failure to report was not interpreted as evidence of absence.

\section{Institutional Processes}

We developed coding criteria for a sub-set of institutional processes from the adaptive co-management, adaptive governance, and $\mathrm{CBC}$ literature used in our conceptual framework. These have been considered as "conditions" that lead to successful outcomes in CBC initiatives. Variables were coded as dichotomous (presence/absence; yes/no). Cases that did not report on these were coded as n/a, or missing, to identify gaps. We first provide some detail about each of the institutional processes with examples from the literature, followed by Table A1 which provides definitions of each, and the specific criteria used to code as present or absent.

1. Established-Established/Not Established: Conservancies that are less than 10 years old are not established, while conservancies older than 10 years are. This is defined by $>$ or equal to 10 years since conservancy started and date of study. This code is consistent with several studies that suggest successful CBC initiatives, and adaptive-comanagement (A-CM), take time to develop (e.g., Seixas and Davy 2008; Seixas and Berkes 2010; Armitage et al. 2009), and from studies in our database that mentioned the year of establishment was an important social variable to consider (e.g., Gandiwa et al., 2013; Naidoo et al. 2011; Collomb et al. 2010).

2. Leadership_Present/Absent: This code refers to whether key players and/or leaders were instrumental in catalyzing the development of a CBC initiative. This characteristic is considered an "ingredient" for successful CBC projects in Seixas and Davy (2008), and is highlighted in the comanagement literature (e.g., Olsson et al. 2007; Plummer 2009; Plummer et al. 2013; Armitage et al. 2009; Plummer and Armitage 2007) as an important condition for successful comanagement projects. In this sense, leaders as "agents of change" provide the windows of opportunity to catalyze the development of CBC initiatives, where they, for example, create value through pulling elements and people together (e.g., technical, funding, and/or political support), express a clear and compelling vision centered around common values and trust, and facilitate an open and interactive dialogue among stakeholders. While strong leadership is considered an important characteristic for the initiation of CBC's and throughout the tenure of a CBC, we use this code to refer only to the presence of strong leadership with these characteristics at the inception of the $\mathrm{CBC}$. This is because the process of collaboration (see collaboration code) captures many elements of leadership, and lack of leadership, once the $\mathrm{CBC}$ has been established, including for 
example, elite capture, lack of openness and inclusiveness in dialogue and transactive decisionmaking regarding $\mathrm{CBC}$ initiatives and management.

3. Bridging or Boundary Organizations_-Present/Absent: This code refers to the role of a particular organization/institution in linking communities across levels of organization, with the purpose of providing a range of services including "raising startup funds; institution building; business networking and marketing; innovation and knowledge transfer; and technical training" (Seixas and Berkes 2010: 183). The importance of these organizations is also emphasized in Berkes (2007), Olsson et al. (2007), Cash and Moser (2000), among others.

4. Diverse and Multiple Partnerships_-Present/Absent: As per Seixas and Berkes (2010), the diversity and number of partnerships is cited as an ingredient for success. In this case, successful cases had between 10-15 partnerships at various scales. Therefore, cases that report $>10$ partnerships are coded as 1 (present), while those that report $<10$ partnerships are coded as 0 (absent). We assume that if partnerships are listed, the list is exhaustive. N/A is used if the vertical/horizontal arrangements are not mentioned in the case study, or if the article happens to be a multiple case study and there is not enough information to determine the number of partnerships that are specific to each case. N/A is also used if the article mentions <10 partnerships, but also mentions "among others", "etc." or something to that effect.

5. Collaboration-Present/Absent: This refers to the communication and negotiation, and transactive decision-making, where emphasis is on shared understanding, diverse inputs, and equity in decision making. This code is used to delineate segments of text that address the ways in which particular governance arrangements are functioning and the collaboration (or not) within CBCs and between organizational levels. It addresses issues of power, elite capture, corruption, transparency and accountability, equity/empowerment in decision making and participation among groups, etc. This was adapted from the comanagement (Plummer and Armitage 2007; Berkes 2009; Armitage et al. 2009) and the CBC-specific literature (e.g., Berkes 2007; Berkes 2004).

6. Social Learning (including Monitoring \& Assessment)—Present/Absent: Social learning refers to the role of experimental and experiential learning (learning by doing), monitoring, and modifying plans/objectives in a reflexive framework. This definition is adapted from the Plummer and Armitage (2007) comanagement framework, and is emphasized in several other comanagement and CBC-specific literature as an important process in CBCs (e.g., Berkes 2004, 2007, 2009; Armitage et al. 2009; Seixas and Berkes 2010).

7. Devolution or rights to local community-Yes/No: This code was used if rights/responsibilities have been devolved to local community members. For instance, in Namibia, conservancies are recognized by the Nature Conservation Amendment Act of 1996, whereby wildlife rights are devolved to communities on communal land. An example from Mburu and Birner (2007) emphasizes how management arrangements can differ; Wildlife Partnerships in Kenya are controlled by the Kenya Wildlife Service, while other arrangements in Kenya develop local county councils where management is devolved to local institutions. Finally, in some cases, the CBC governance model could have provided some rights to local communities to allocate funds to building physical infrastructure, but were described overall as top-down and prescriptive, which limited options of local communities to take control of management decisions (e.g., Marks 2001). 
8. Monetary Incentives - Yes/No: This code (and nonmonetary incentives) is derived from Berkes (2004) and Seixas and Berkes (2010), in addition to several other studies that discuss the benefits and detriments of direct incentives (those incentives that are given directly to household members and/or participating members of the $\mathrm{CBC}$ ) and indirect incentives (those incentives that support community development; e.g., Saarinen 2010; Silva and Mosimane 2012, 2014; Gibson and Marks 1995). Some emphasize one over the other, for example the importance of providing direct incentives will deter the free-rider problem, while indirect incentives will offset cost of community members who do not benefit directly from conservation but bear much of the costs. Although CBCs are traditionally structured around the premise that community members protect wildlife/resources in exchange for economic (monetary) incentives, many community members do not consider these adequate incentives. Therefore, there is a mismatch between what conservationists consider sufficient benefits, and what communities do. In many cases, communities consider equal participation in decision-making processes, education/training opportunities, and land tenure arrangements as, if not more, important than direct benefits.

9. Non-Monetary Incentives - Yes/No: This code (and monetary incentives) is derived from Berkes (2004) and Seixas and Berkes (2010), in addition to several other studies that discuss the benefits and negatives of direct incentives (those incentives that are given directly to household members and/or participating members of the $\mathrm{CBC}$ ) and indirect incentives (those incentives that support community development; e.g., Saarinen 2010; Silva and Mosimane 2012, 2014; Gibson and Marks 1995). Some emphasize one over the other, for example the importance of providing direct incentives will deter the free-rider problem, while indirect incentives will offset cost of community members who do not benefit directly from conservation but bear much of the costs. Although CBCs are traditionally structured around the premise that community members protect wildlife/resources in exchange for economic (monetary) incentives, many community members do not consider these adequate incentives. Therefore, there is a mismatch between what conservationists consider sufficient benefits, and what communities do. In many cases, communities consider equal participation in decision-making processes, education/training opportunities, and land tenure arrangements as, if not more, important than direct monetary benefits.

10. Conservation model in-line with cultural worldviews and practices-Yes/No: This code stems from Berkes' (2004) emphasis on incorporation of Traditional and Local Ecological Knowledge into $\mathrm{CBC}$ projects and developing a cross-cultural conservation ethic. In other words to ensure that $\mathrm{CBC}$ is compatible with cultural models and views regarding people-nature relationships, and in many cases developing $\mathrm{CBCs}$ for resource and wildlife sustainability in places/cultures where sustaining these resources and wildlife is consistent with cultural worldviews (e.g., establishing a Hippo Sanctuary in an area where local groups have taboos against killing Hippos, (Sheppard et al. 2010), and does not infringe on cultural/livelihood practices (e.g., Songorwa 1999; Dyer et al. 2014). This was expanded on by a recent article Gavin et al. (2015).

Table 1.1. Description of institutional processes, or conditions, and their sources.

\begin{tabular}{|l|l|l|l|}
\hline Processes/Conditions & Code & Explanation & Sources \\
\hline Year Established & Established & $>10$ years old & $\begin{array}{l}\text { Seixas \& Davy, 2008; } \\
\text { Seixas \& Berkes, 2010; } \\
\text { Armitage et al., 2009; } \\
\text { Gandiwa et al., 2013 }\end{array}$ \\
\hline & & & \\
\hline
\end{tabular}




\begin{tabular}{|c|c|c|c|}
\hline Leadership/Key players & Present & At inception of a CBC & $\begin{array}{l}\text { Seixas \& Davy, 2008; } \\
\text { Olsson et al., 2007; } \\
\text { Plummer, 2009; } \\
\text { Plummer et al., 2013; } \\
\text { Plummer \& Armitage, } \\
2007\end{array}$ \\
\hline & Absent & & \\
\hline \multirow[t]{2}{*}{$\begin{array}{l}\text { Bridging/Boundary } \\
\text { Organizations }\end{array}$} & Present & $\begin{array}{l}\text { Links communities } \\
\text { across levels of } \\
\text { organization }\end{array}$ & $\begin{array}{l}\text { Seixas \& Berkes, 2010; } \\
\text { Berkes, 2007; Cash \& } \\
\text { Moser, 2000; Olsson et } \\
\text { al., } 2007\end{array}$ \\
\hline & Absent & & \\
\hline \multirow{2}{*}{$\begin{array}{l}\text { Diverse/Multiple } \\
\text { Partnerships }\end{array}$} & Present & $>10$ partnerships & Seixas \& Berkes, 2010 \\
\hline & Absent & $<10$ partnerships & \\
\hline \multirow[t]{2}{*}{ Collaboration } & Present & $\begin{array}{l}\text { Transparency, equity, } \\
\text { communication }\end{array}$ & $\begin{array}{l}\text { Armitage et al., 2009; } \\
\text { Berkes, 2009, 2007, } \\
\text { 2004; Plummer \& } \\
\text { Armitage, } 2007\end{array}$ \\
\hline & Absent & & \\
\hline \multirow[t]{2}{*}{ Social Learning } & Present & $\begin{array}{l}\text { Learning by doing, } \\
\text { monitoring and } \\
\text { assessment }\end{array}$ & $\begin{array}{l}\text { Armitage et al., 2009; } \\
\text { Berkes, 2009, 2007, } \\
\text { 2004; Plummer \& } \\
\text { Armitage, 2007; Seixas } \\
\text { \& Berkes, 2010 }\end{array}$ \\
\hline & Absent & & \\
\hline \multirow[t]{2}{*}{$\begin{array}{l}\text { Devolution of rights to } \\
\text { local community }\end{array}$} & Yes & $\begin{array}{l}\text { Rights/responsibilities } \\
\text { devolved to local } \\
\text { community }\end{array}$ & $\begin{array}{l}\text { Mburu \& Birner, 2007; } \\
\text { Marks, } 2001\end{array}$ \\
\hline & No & & \\
\hline \multirow[t]{2}{*}{ Monetary Incentives } & Yes & $\begin{array}{l}\text { Individual/household; } \\
\text { financial capital }\end{array}$ & $\begin{array}{l}\text { Seixas \& Berkes, 2010; } \\
\text { Berkes, 2004; Silva \& } \\
\text { Mosimane, 2012, } 2014\end{array}$ \\
\hline & No & & \\
\hline \multirow[t]{2}{*}{$\begin{array}{l}\text { Non-monetary } \\
\text { incentives }\end{array}$} & Yes & $\begin{array}{l}\text { Individual and/or } \\
\text { community; human, } \\
\text { social, and physical } \\
\text { capital }\end{array}$ & $\begin{array}{l}\text { Berkes, 2004; Saarinen, } \\
\text { 2010; Gibson \& Marks, } \\
\text { 1995; Sliva \& } \\
\text { Mosimane, } 2012\end{array}$ \\
\hline & No & & \\
\hline \multirow[t]{2}{*}{$\begin{array}{l}\text { Cultural } \\
\text { Worldviews/Practices } \\
\text { Considered in } \\
\text { Conservation Model }\end{array}$} & Yes & $\begin{array}{l}\text { Links between local, } \\
\text { traditional, and } \\
\text { traditional ecological } \\
\text { knowledge with; cross- } \\
\text { cultural conservation } \\
\text { ethic }\end{array}$ & $\begin{array}{l}\text { Berkes, 2004, Sheppard } \\
\text { et al., 2010; Dyer et al., } \\
\text { 2014; Songorwa, 1999; } \\
\text { Gavin et al., } 2015\end{array}$ \\
\hline & No & & \\
\hline
\end{tabular}




\section{ADDITIONAL LITERATURE CITED}

Cash, D. W., and S. Moser. 2000. Linking global and local scales: designing dynamic assessment and management processes. Global Environmental Change 10:109-120.

Gavin, M. C., J. McCarter, A. Mead, F. Berkes, J. R. Stepp, D. Peterson, and R. Tang. 2015. Defining biocultural approaches to conservation. Trends in Ecology \& Evolution 30(3):140-145. DOI:

10.1016/j.tree.2014.12.005

Olsson, P., C. Folke, V. Galaz, T. Hahn, and L. Schultz. 2007. Enhancing the fit through adaptive comanagement: creating and maintaining bridging functions for matching scales in the Kristianstads Vattenrike Biosphere Reserve Sweden. Ecology and Society 12(1): 28. [online] URL: http://www.ecologyandsociety.org/vol12/iss1/art28/

Plummer, R. 2009. The adaptive co-management process: an initial synthesis of representative models and influential variables. Ecology and Society 14(2): 24. [online] URL:

http://www.ecologyandsociety.org/vol14/iss2/art24/

Saarinen, J. 2010. Local tourism awareness: Community views in Katutura and King Nehale conservancy, Namibia. Development Southern Africa 27(5):713-724. DOI: 10.1080/0376835X.2010.522833

Silva, J. A., and A. W. Mosimane. 2012. Conservation-based rural development in Namibia: A mixedmethods assessment of economic benefits. The Journal of Environment \& Development 22(1):25-50. DOI: $10.1177 / 1070496512469193$

\section{Social and Ecological Outcomes}

Tables 1.2 and 1.3 define and provide examples of each of the social and ecological outcomes that were coded for in this review.

Table 1.2. Description of capital assets used to code social outcomes in the review (adapted from Plummer and Armitage, 2007 and DfID, 1999)

\begin{tabular}{|l|l|}
\hline Social Capital & $\begin{array}{l}\text { Networks, connections, trust, shared values, leadership, } \\
\text { common rules and sanctions, mechanisms for participation } \\
\text { in decision-making, leadership, pride/emotional investment }\end{array}$ \\
\hline Human Capital & $\begin{array}{l}\text { Health, education, capacity to work, gain new skills, } \\
\text { security }\end{array}$ \\
\hline Physical Capital & Infrastructure, tools, technology, water, communications \\
\hline Financial Capital & $\begin{array}{l}\text { Savings, wages, economic diversification, financial } \\
\text { independence, poverty alleviation }\end{array}$ \\
\hline $\begin{array}{l}\text { Equal Distribution of } \\
\text { Benefits }^{ \pm}\end{array}$ & The benefits are evenly distributed across CBC members \\
\hline
\end{tabular}

+Security (from conflict due to e.g., livestock raiding, poaching) was added as it was found to be important in a number of cases 
\pm Found to be important in some of the cases

Table 1.3. Description of parameters used to code ecological outcomes in the review (adapted from Plummer and Armitage, 2007)

\begin{tabular}{|l|l|}
\hline Components & $\begin{array}{l}\text { All living and non-living material, e.g., keystone species, } \\
\text { vegetation communities }\end{array}$ \\
\hline Relationships & $\begin{array}{l}\text { Underlying processes and interaction to ecological patterns, e.g., } \\
\text { biomass productivity, nutrient cycling, change in vegetation }\end{array}$ \\
\hline Diversity/Redundancy & Species richness and diversity \\
\hline Memory/Continuity & $\begin{array}{l}\text { The ways species and processes are linked through space and } \\
\text { time, e.g., edge effects, ecosystem/habitat integrity and } \\
\text { connectivity, patchiness, fragmentation }\end{array}$ \\
\hline
\end{tabular}


Appendix 2. Appendix B. Case studies used in the spatial analysis.

Please click here to download file 'appendix2.xlsx'. 
Ecology and Society 23(3): 39

Appendix 3. Appendix C. Case studies used in the detailed textual analysis

Please click here to download file 'appendix3.xlsx'. 
Appendix 4. Cases excluded from review based on exclusion criteria.

1. Asare, R. A., A. Kyei, and J. J. Mason. 2013. The community resource management area mechanism: a strategy to manage African forest resources for REDD+. Philosophical Transactions of the Royal Society B: Biological Sciences 368(1625):2012031120120311.

2. Ashley, C. 2000. The impact of tourism on rural livelihoods: Namibia's experience. Overseas Development Institute, London.

3. Baker, J., E. J. Milner-Gulland, and N. Leader-Williams. 2012. Park Gazettement and Integrated Conservation and Development as Factors in Community Conflict at Bwindi Impenetrable Forest, Uganda: Drivers of Community Conflict at Bwindi. Conservation Biology 26(1):160-170.

4. Bandyopadhyay, S., M. Humavindu, P. Shyamsundar, and L. Wang. 2009. Benefits to local communities from community conservancies in Namibia: An assessment. Development Southern Africa 26(5): 733-754.*

5. Bedelian, C. 2014. Conservation, tourism and pastoral livelihoods: Wildlife conservancies in the Maasai Mara, Kenya. University College London, London, UK.

6. Beh, A. 2011. Do you see what I see? Photovoice, community-based research, and conservation education in Samburu, Kenya. Colorado State University, Fort Collins, CO.

7. Blaikie, P. 2006. Is Small Really Beautiful? Community-based Natural Resource Management in Malawi and Botswana. World Development 34(11):1942-1957.

8. Bollig, M., and D. A. Menestrey Schwieger. 2014. Fragmentation, Cooperation and Power: Institutional Dynamics in Natural Resource Governance in North-Western Namibia. Human Ecology 42(2):167-181.

9. Brown, H. C. P., and J. P. Lassoie. 2010. Institutional choice and local legitimacy in community-based forest management: lessons from Cameroon. Environmental Conservation 37(03):261-269.

10. Buch, A., and A. B. Dixon. 2009. South Africa's working for water programme: searching for win-win outcomes for people and the environment. Sustainable Development 17(3):129-141.

11. Campbell, B., and S. Shackleton. 2001. The Organizational Structures for CommunityBased Natural Resources Management in Southern Africa. African Studies Quarterly $5(3): 28$.

12. Child, B., and G. Barnes. 2010. The conceptual evolution and practice of communitybased natural resource management in southern Africa: past, present and future. Environmental Conservation 37(03):283-295.

13. Constantino, P. de A. L., H. S. A. Carlos, E. E. Ramalho, L. Rostant, C. E. Marinelli, D. Teles, S. F. Fonseca-Junior, R. B. Fernandes, and J. Valsecchi. 2012. Empowering Local People through Community-based Resource Monitoring: a Comparison of Brazil and Namibia. Ecology and Society 17(4).

14. Davis, A. P. (n.d.). Consequences of 'Conservation': A Critical Look at Namibian Communal Conservancies:13. 
15. Dougill, A. J., L. C. Stringer, J. Leventon, M. Riddell, H. Rueff, D. V. Spracklen, and E. Butt. 2012. Lessons from community-based payment for ecosystem service schemes: from forests to rangelands. Philosophical Transactions of the Royal Society B: Biological Sciences 367(1606):3178-3190

16. Frost, P. G. H., and I. Bond. 2008. The CAMPFIRE programme in Zimbabwe: Payments for wildlife services. Ecological Economics 65(4):776-787.

17. Hackel, JD. 1999. Community Conservation and the Future of Africa's Wildlife. Conservation Biology 13(4):726-734.

18. Harrison, E. P., L. C. Stringer, and A. J. Dougill. (n.d.). The importance of the subdistrict level for community-based natural resource management in rural Zimbabwe. Centre for Climate Change Economics and Policy Working Paper No. 183, Sustainability Research Institute, Leeds, UK.

19. Hayward, M. W., G. I. H. Kerley, J. Adendorff, L. C. Moolman, J. O’Brien, A. SholtoDouglas, C. Bissett, P. Bean, A. Fogarty, D. Howarth, and R. Slater. 2007. The reintroduction of large carnivores to the Eastern Cape, South Africa: an assessment. Oryx 41(02):205.

20. Heinemeyer, K.S., R. Karimi, V. Kasupi, and J. Smith. 2014. Kuene regional ecological analyses: Assisting conservancies with seasonal wildlife monitoring. 2013-14 Progress Report to the Namibia Ministry of Environment and Tourism, September 2, 2014.

21. Hoole, A. 2007. Lessons from the Equator Initiative: Common Property Perspectives for Community-Based Conservation in Southern Africa and Namibia. Pages 32. International Development Research Center and United Nations Development Programme, Winnipeg, MB, Canada.

22. Hoole, A., and F. Berkes. 2010. Breaking down fences: Recoupling social-ecological systems for biodiversity conservation in Namibia. Geoforum 41(2):304-317.

23. Humavindu, M.N., and J. Stage. 2015. Community-based wildlife management failing to link conservation and financial viability. Animal Conservation 18: 4-13.*

24. Ikubolajeh Logan, B., and W. J. Moseley. 2002. The political ecology of poverty alleviation in Zimbabwe's Communal Areas Management Programme for Indigenous Resources (CAMPFIRE). Geoforum 33:1-14.

25. Jandreau, C. P. 2014. [De] constructing a partnership: Evaluating a win-win conservation and development story, the case of the Mara conservancies, Kenya. University of Manitoba, Winnipeg, Canada.

26. Johansson, K.-E., R. Axelsson, N. Kimanzu, S. Sassi, E. Bwana, and R. Otsyina. 2013. The Pattern and Process of Adoption and Scaling up: Variation in Project Outcome Reveals the Importance of Multilevel Collaboration in Agroforestry Development. Sustainability 5(12):5195-5224.

27. Jonathan, L. T. 2012. The role of community-based conservation on poverty reduction in Westgate Community Conservancy in Samburu County. University of Nairobi, Nairobi, Kenya.

28. Jones, B. T. B. 1999. Policy lessons from the evolution of a community-based approach to wildlife management, Kunene Region, Namibia. Journal of International Development 11(2):295-304. 
29. Jones, J. P. G., F. B. Andriahajaina, E. H. Ranambinintsoa, N. J. Hockley, and O. Ravoahangimalala. 2006. The economic importance of freshwater crayfish harvesting in Madagascar and the potential of community-based conservation to improve management. Oryx 40(02): 168 .

30. Kahler, J. S., G. J. Roloff, and M. L. Gore. 2013. Poaching Risks in Community-Based Natural Resource Management: Poaching and Community-Based Management. Conservation Biology 27(1):177-186.

31. Kanapaux, W., and B.Child. 2011. Livelihood activities in a Namibian wildlife conservancy: A case study of variation within a CBNRM programme. Oryx 45(3): 365372.

32. Kelso, A., and M. Jacobson. 2011. Community assessment of agroforestry opportunities in GaMothiba, South Africa. Agroforestry Systems 83(3):267-278.

33. Kiss, A. 2004. Is community-based ecotourism a good use of biodiversity conservation funds? TRENDS in Ecology and Evolution 19(5): 232-237.

34. Kreuter, U., M. Peel, and E. Warner. 2010. Wildlife Conservation and Community-Based Natural Resource Management in Southern Africa's Private Nature Reserves. Society \& Natural Resources 23(6):507-524.

35. Kull, C. A. (n.d.). Empowering pyromaniacs in Madagascar: ideology and legitimacy in community-based resource management:20.

36. Low, B., S. R. Sundaresan, I. R. Fischhoff, and D. I. Rubenstein. 2009. Partnering with local communities to identify conservation priorities for endangered Grevy's zebra. Biological Conservation 142(7):1548-1555.

37. Lyons, A. 2013. The Rise and Fall of a Second-Generation CBNRM Project in Zambia: Insights from a Project Perspective. Environmental Management 51(2):365-378.

38. Marcus, R. 2001. Seeing the Forest for the Trees: Integrated Conservation and Development Projects and Local Perceptions of Conservation in Madagascar. Human Ecology 29(4):381-397.

39. Matose, F., and S. Watts. 2010. Towards community-based forest management in Southern Africa: do decentralization experiments work for local livelihoods? Environmental Conservation 37(03):310-319.

40. Mbaiwa, J.E., A. Stronza, and U. Kreuter. 2011. From collaboration to conservation: Insights from the Okavango Delta, Botswana. Society and Natural Resources: An International Journal 24(4): 400-411.*

41. McCall, MK, and Peter A. Minang. 2005. Assessing Participatory GIS for CommunityBased Natural Resource Management: Claiming Community Forests in Cameroon. The Geographical Journal 171(4):340-356.

42. McDermott Hughes, D. 2001. Cadastral Politics: The Making of Community-Based Resource Management in Zimbabwe and Mozambique. Development and Change 32(4):741-768.

43. Measham, T. G., and J. A. Lumbasi. 2013. Success Factors for Community-Based Natural Resource Management (CBNRM): Lessons from Kenya and Australia. Environmental Management 52(3):649-659. 
44. Murphree, M. W. 2009. The strategic pillars of communal natural resource management: benefit, empowerment and conservation. Biodiversity and Conservation 18(10):25512562.

45. Naidoo, R., L. C. Weaver, M. De Longcamp, and P. Du Plessis. 2011. Namibia's community-based natural resource management programme: an unrecognized payments for ecosystem services scheme. Environmental Conservation 38(04):445-453.

46. Naidoo, R., G. Stuart-Hill, L.C. Weaver, J. Tagg, A. Davis, and A. Davidson. 2011A. Effect of diversity of large wildlife species on financial benefits to local communities in northwest Namibia. Environmental and Resource Economics 48: 321-335.*

47. Naidoo, R., L.C. Weaver, G. Stuart-Hill, and J. Tagg. 2011B. Effects of biodiversity on economic benefits from communal lands in Namibia. Journal of Applied Ecology 48: 310-316. *

48. Naidoo, R., and K. Johnson. 2013. Community-based conservation reduces sexual risk factors for HIV among men. Globalization and Health 9: 27.*

49. Nelson, F., C. Foley, L. S. Foley, A. Leposo, E. Loure, D. Peterson, M. Peterson, T. Peterson, H. Sachedina, and A. Williams. 2010. Payments for Ecosystem Services as a Framework for Community-Based Conservation in Northern Tanzania. Conservation Biology 24(1):78-85.

50. Nkhata, B. A., and C. M. Breen. 2010. Performance of community-based natural resource governance for the Kafue Flats (Zambia). Environmental Conservation 37(03):296-302.

51. Alexander, J., and J. A. McGregor. 2000. Wildfire and politics: Campfire in Zimbabwe. Development and Change 31:605-627.

52. Osano, P. M., M. Y. Said, J. de Leeuw, S. S. Moiko, D. Ole Kaelo, S. Schomers, R. Birner, and J. O. Ogutu. 2013. Pastoralism and ecosystem-based adaptation in Kenyan Masailand. International Journal of Climate Change Strategies and Management 5(2):198-214.

53. Pacheco, L., S. Fraixedas, Á. Fernández-Llamazares, N. Estela, R. Mominee, and F. Guallar. 2012. Perspectives on Sustainable Resource Conservation in Community Nature Reserves: A Case Study from Senegal. Sustainability 4(12):3158-3179.

54. Parkinson, C. A. 2012. The political ecology of community conservation in northern Kenya: A case study of the Meibae Community Wildlife Conservancy. University of Toronto, Toronto, Canada.

55. Patenaude, G., and K. Lewis. 2014. The impacts of Tanzania's natural resource management programmes for ecosystem services and poverty alleviation. International Forestry Review 16(4):459-473.

56. Paterson, B., G. Stuart-Hill, L. G. Underhill, T. T. Dunne, B. Schinzel, C. Brown, B. Beytell, F. Demas, P. Lindeque, J. Tagg, and C. Weaver. 2008. A fuzzy decision support tool for wildlife translocations into communal conservancies in Namibia. Environmental Modelling \& Software 23(5):521-534.

57. Peters, J. 1988. Transforming the Integrated Conservation and Development Project (ICDP) approach: Observations from the Ranomafana National Park project, Madagascar. Journal of Agricultural and Environmental Ethics 11(1):17-47. 
58. Pienaar, E. F., L. S. Jarvis, and D. M. Larson. 2013. Creating Direct Incentives for Wildlife Conservation in Community-Based Natural Resource Management Programmes in Botswana. Journal of Development Studies 49(3):315-333.

59. Pye-Smith, C. 2013. The story of the northern rangelands trust: conserving wildlife, transforming lives, restoring peace. Pages 52. Northern Rangelands Trust, Isiolo, Kenya.

60. Riehl, B., H. Zerriffi, and R. Naidoo. 2015. Effects of community-based natural resource management on household welfare in Namibia. PLOS ONE 10(5): e0125531.*

61. Robinson, L. W. 2008. Lessons from the Equator Initiative: Institutional Linkages, Approaches to Public Participation, and Social-Ecological Resilience for Pastoralists in Northern Kenya. Pages 29. International Development Research Center and United Nations Development Programme, Winnipeg, MB, Canada.

62. Robinson, L. W., and F. Berkes. 2011. Multi-level participation for building adaptive capacity: Formal agency-community interactions in northern Kenya. Global Environmental Change 21(4):1185-1194.

63. Robinson, E. J. Z., H. J. Albers, C. Meshack, and R. B. Lokina. 2013. Implementing REDD through community-based forest management: Lessons from Tanzania. Natural Resources Forum 37(3):141-152.

64. Saarinen, J. 2010. Local tourism awareness: Community views in Katutura and King Nehale Conservancy, Namibia. Development Southern Africa 27(5): 713-724.

65. Sandker, M., B. M. Campbell, Z. Nzooh, T. Sunderland, V. Amougou, L. Defo, and J. Sayer. 2009. Exploring the effectiveness of integrated conservation and development interventions in a Central African forest landscape. Biodiversity and Conservation 18(11):2875-2892.

66. Sanginga, P. C., R. N. Kamugisha, and A. M. Martin. 2007. The dynamics of social capital and conflict management in multiple resource regimes: a case of the southwestern highlands of Uganda. Ecology and Society 12(1):6.

67. Seixas, C. S., and F. Berkes. 2010. Community-based enterprises: the significance of partnerships and institutional linkages. International Journal of the Commons 4(1):183212.

68. Silva, J.A., and A.W. Mosimane. 2012. Conservation-based rural development in Namibia: A mixed-methods assessment of economic benefits. Journal of Environment and Development 22(1): 25-50.*

69. Snider, R. T. 2012. Land Tenure, Ecotourism, and Sustainable Livelihoods: „Living on the Edge" of the Greater Maasai Mara, Kenya. University of Waterloo, Waterloo, Ontario, Canada.

70. Sørlie, E. B. 2008. The establishment of wildlife conservancies in the Mara: The case of Olare Orok Conservancy. University of Oslo, Oslo, Norway.

71. Stuart-Hill, G., R. Diggle, B. Munali, J. Tagg, and D. Ward. 2005. The Event Book System: A Community-based Natural Resource Monitoring System from Namibia. Biodiversity and Conservation 14(11):2611-2631.

72. Suich, H. 2010. The livelihood impacts of the Namibian community based natural resource management programme: a meta-synthesis. Environmental Conservation 37(01):45-53. 
73. Taylor, J. J. 2008. Naming the land: San countermapping in Namibia's West Caprivi. Geoforum 39(5):1766-1775.

74. Taylor, R. 2009. Community based natural resource management in Zimbabwe: the experience of CAMPFIRE. Biodiversity and Conservation 18(10):2563-2583.

75. Thouless, C., R. W. Diggle, and C. Sikoppo. 2014. New tourism concessions in National Parks to benefit community conservancies in Namibia. Oryx 48(03):327-328.

76. Turpie, J. K., C. Marais, and J. N. Blignaut. 2008. The working for water programme: Evolution of a payments for ecosystem services mechanism that addresses both poverty and ecosystem service delivery in South Africa. Ecological Economics 65(4):788-798.

77. Virtanen, P. 2005. Community-based natural resource management in Mozambique: a critical review of the concept's applicability at local level. Sustainable Development 13(1):1-12.

78. Zunckel, K. 2003. Managing and Conserving Southern African Grasslands With High Endemism. Mountain Research and Development 23:113-118.

*Cases included in spatial analysis but excluded from detailed analysis because aggregates cases. This allowed for more accurate assessment of individual cases in the detailed analysis. 